\title{
The impact of financial education on adolescents' intertemporal choices
}

IFS Working Paper W14/18

Melanie Lührmann

Marta Serra-Garcia

Joachim Winter 
The Institute for Fiscal Studies (IFS) is an independent research institute whose remit is to carry out rigorous economic research into public policy and to disseminate the findings of this research. IFS receives generous support from the Economic and Social Research Council, in particular via the ESRC Centre for the Microeconomic Analysis of Public Policy (CPP). The content of our working papers is the work of their authors and does not necessarily represent the views of IFS research staff or affiliates. 


\title{
The Impact of Financial Education on Adolescents' Intertemporal Choices*
}

\author{
Melanie Lührmann† Marta Serra-Garcia ${ }^{\ddagger}$ and Joachim Winter ${ }^{\S}$
}

April 27, 2015

\begin{abstract}
We study the impact of financial education on intertemporal choice in adolescence. The program was randomly assigned among high-school students and intertemporal choices were measured using an incentivized experiment. Students who participated in the program display a decrease in time inconsistency; an increase in the allocation of payment to a single payment date, compared to spreading payment across two dates; and increased consistency of choice with the law of demand. These findings suggest that the effect of such educational programs is to increase comprehension and decrease bracketing in intertemporal choice.
\end{abstract}

JEL codes: D14, D91, C93.

Keywords: Intertemporal Choice, Financial Education, Experiment.

${ }^{*}$ First version: July 24, 2014. We would like to thank Jim Andreoni, Leandro Carvalho, Marco Castillo, Hans-Martin von Gaudecker, Martin Kocher, Amrei Lahno, Daniel Schunk and Charlie Sprenger, for helpful comments, as well as the audiences at numerous seminars and conferences. We would like to thank the team of My Finance Coach for their support in the implementation of the study, and David Bauder, Daniela Eichhorn, Felix Hugger, Johanna Sophie Quis, and Angelica Schmidt for excellent research assistance. Finally, we would like to thank Anton Vasilev for programming the web interface for randomization. This project was conducted under IRB140988XX and benefitted from the support of internal funds of the University of Munich.

${ }^{\dagger}$ Institute for Fiscal Studies, London; Royal Holloway, University of London; and Munich Center for the Economics of Aging (MEA). E-mail: melanie.luhrmann@rhul.ac.uk

${ }^{\ddagger}$ Rady School of Management, University of California, San Diego. Corresponding author. E-mail: mserragarcia@ucsd.edu

$\S$ University of Munich and Munich Center for the Economics of Aging (MEA). E-mail: winter@lmu.de 


\section{Introduction}

Time preferences are central to economic decision-making. They influence important decisions such as investment in education, mortgage borrowing, and saving for retirement. Yet, the sources of heterogeneity in time preferences are not well understood. Becker and Mulligan (1997) argue that education may shape patience, as it can decrease the costs of appreciating the future. This raises the question whether educational interventions could affect time preferences.

In this paper, we randomly assign participation in a financial education program among adolescents and examine whether the program has an effect on intertemporal choice. There are two central challenges in the identification of the effects of education on preferences. First, education must not be tailored to the experimental task. Clearly, if the educational program discusses choices in the context of the elicitation mechanism, no inference can be made about its effect on preferences. ${ }^{1}$ The educational program we examine discusses spending, planning and savings behavior, as it applies to everyday choices of adolescents. It does not discuss interest rates and is unrelated to the elicitation mechanism.

The second challenge is that the mechanism used to elicit intertemporal choices must measure the parameters of interest. If the mechanism uses time-dated monetary payments, several issues arise: subjects can arbitrage payments offered through the mechanism and they may broadly bracket their decisions (Frederick, Loewenstein and O'Donoghue, 2002; Cubitt and Read, 2007; Chabris, Laibson and Schuldt, 2008; Sprenger, 2015). If they do so, experimental choices would not be informative about time preferences. However, several studies show that, among adults and children, experimental choices systematically correlate with field behaviors (e.g., Castillo et al., 2011;

\footnotetext{
${ }^{1}$ This is related to the problem of inference regarding skill improvement in education when "teaching to the test" is possible (Neal, 2013).
} 
Chabris et al., 2008; Moffitt et al., 2011; and Sutter et al., 2013). For example, Sutter et al. (2013) find that adolescents who exhibit more impatience in their intertemporal choices are less likely to save. Thus far, little is known about when choices reflect arbitrage opportunities and broad bracketing and when they do not.

Our elicitation mechanism is based on the Convex Time Budget (CTB) task (Andreoni and Sprenger, 2012). The CTB task allows individuals to spread the payments offered by the experimenter across two payment dates, or to allocate the entire payment either to the sooner or to the later payment date. ${ }^{2}$ An implication of arbitrage and broad bracketing in this task is that individuals should primarily select corner choices, i.e., allocate their budget to a single payment date. More broadly, if payments are not treated as consumption, individuals should be less time inconsistent. In other words, they should be less likely to exhibit stronger impatience when sooner payments are immediate - a behavior that is predicted in models of temptation and self-control (e.g., Laibson, 1997; O’Donoghue and Rabin, 1999; Gul and Pesendorfer, 2001).

We show that these two features of choice are related to participation in the financial education program. The treatment leads to an increase in the frequency with which corner choices are selected and decreases time inconsistency, i.e., treated students are less likely to increase the share allocated to the sooner payment when the sooner payment is immediate. Two additional choice patterns that are consistent with arbitrage and broad bracketing are observed among treated students. First, demand curves become more downward sloping. That is, choices become more consistent with the law of demand, a measure of the quality of decision-making (Giné et al., 2012; Choi et al., 2014). Second, there is a weaker relationship between external savings behavior and

\footnotetext{
${ }^{2}$ Previous experimental tasks using choice lists only allow corner choices, i.e. individuals allocate the entire budget either to the sooner or to the later payment date. Early studies among adults include Coller and Williams (1999) and Harrison, Lau and Williams (2002), while the first study among children was conducted by Bettinger and Slonim (2007). To allow for concave utility when estimating time preference parameters, several studies have elicited risk preferences separately (e.g., Andersen et al., 2008, Sutter et al., 2013).
} 
experimental choices among treated students, which suggests that experimental choices may have become less informative about preferences. ${ }^{3}$

Taken together, our results indicate that educational interventions may influence intertemporal choice, but are more closely related to comprehension and bracketing than to changes in preferences. This is an important finding, in light of recent results suggesting that the quality of decision making is strongly positively correlated with wealth accumulation (Choi et al., 2014). ${ }^{4}$ Our focus is on an increasingly popular type of educational intervention, a short financial education program. Further work is needed to understand the effects of more intensive educational interventions.

Our paper contributes to two important literatures. First, our work relates to research concerned with arbitrage in experiments using time-dated monetary payments. The only study that directly examines the role of arbitrage is Coller and Williams (1999), who provide subjects with information about market interest rates. Our findings reveal that financial education programs can lead to patterns of intertemporal choice that are characteristic of broad bracketing and arbitrage opportunities when individuals are offered time-dated payments. ${ }^{5}$ Arbitrage and bracketing are not the only concerns in experiments using time-dated monetary payments. A related discussion concerns external consumption opportunities (Carvalho, Meier and Wang, 2014; Dean and Sautmann, 2014). In our sample we do not observe a significant change in allowance money, spending and saving in response to participation in the program, suggesting that the program did not lead to a change in external consumption opportunities.

\footnotetext{
${ }^{3} \mathrm{~A}$ further consequence of arbitrage opportunities for individuals who have perfect access to credit markets is that imputed discount rates should converge to market interest rates. Since this study concentrates on adolescents who do not have direct access to credit markets, we would not expect this prediction to hold.

${ }^{4}$ Choi et al. (2014) use a revealed preference method based on GARP and measure consistency using Afriat's (1972) Critical Cost Efficiency Index (CCEI).

${ }^{5}$ Recent studies using the Convex Time Budget task have also found an increase in the frequency with which individuals choose to allocate their entire budget to a single payment date in response to willpower manipulations (Kuhn, Kuhn and Villeval, 2013) and after the introduction of savings accounts (Carvalho, Prina and Sydnor, 2014).
} 
Second, our paper contributes to the debate on the impact of financial education programs. Financial education has become increasingly common in recent years, reaching in 2013 an estimated 670 million US dollars spent annually in such programs (CFPB, 2013; Lusardi and Mitchell, 2014). However, the effects of financial education programs among adults are often found to be weak or inexistent (see Lynch, Fernandes and Netemeyer, 2014, for a review). Existing studies of financial education among adolescents find that such programs increase savings. Bruhn et al. (2013) find long-term effects on savings one year after a two-year long program ended in Brazil, while Berry, Karlan and Pradhan (2015) find similar short-term effects, after a nine-month long program in Ghana. ${ }^{6}$ Our study focuses on the effects of financial education on incentivized intertemporal choices, to examine which dimensions of intertemporal choice, if any, are affected by the program. Our results suggest an indirect effect of the program on future savings, as the quality of decision making, which has been shown to relate to wealth accumulation (Choi et al., 2014), improves.

The remainder of the paper proceeds as follows. In the next section we describe the financial education program. In Section 3 we describe the experimental task and methods used. Section 4 reports the descriptive results. In Section 5 we present the results of a structural estimation approach of aggregate and individual preference parameters that allows for stochastic errors in choices. Section 6 concludes.

\section{The Financial Education Program}

The financial education program is provided by a non-profit organization, My Finance Coach, which since its startup in October 2010 has offered financial education to over 35,000 German high school students, aged mainly between 13 and 15 years (My Finance

\footnotetext{
${ }^{6}$ Other studies of financial education among adolescents, which have focused on the effect of such programs on knowledge, attitudes and self-reported behaviors, find mixed results (e.g., Becchetti, Caiza and Covello, 2013; Lührmann et al., 2015).
} 
Coach, 2012). We evaluate the impact of financial education offered through visits of "finance coaches" to schools. These coaches are employees of the (for-profit) firms that sponsor the (non-profit) provider, and they are not compensated for the training they provide to high-school students. They volunteer to conduct several visits of 90 minutes, for a total of 4.5 hours, each of which is dedicated to one of the training modules. The provider offers a set of materials for each module and trains the coaches; hence, visits are standardized.

This financial education program is well suited for studying the impact of educational interventions among adolescents. First, it is provided at schools, and hence all students in a class participate, avoiding selection problems (see, e.g., Meier and Sprenger, 2013). Second, the materials taught are standardized, have been developed by educational experts (ranging from education researchers to school directors), and have been extensively used in teaching for over four years in Germany. Third, this educational intervention is scalable.

We measure the joint impact of three training modules that are provided to all treated students: Shopping, Planning, and Saving. Each module deals with the following topics as described in the official materials of the provider. Detailed information of each module is provided in Table $1 .^{7}$ The Shopping module deals with acting as an informed consumer. It focuses on prioritizing spending ("needs and wants"), discusses criteria used in purchasing decisions and advertising. The Planning module addresses aspects of conscious planning. It presents the concepts of income and expenditure as the basis of financial planning, and trains budgeting skills. The last module, Saving, discusses different saving motives and various types of investment options. The training does not take a normative position on saving, but discusses how to save. Importantly, the training also does not involve any decision that directly resembles the tradeoffs in

\footnotetext{
${ }^{7}$ Further detailed information about the training materials can be found at http://en. myfinancecoach.org/.
} 


\section{the Convex Time Budget task.}

\section{Table 1: Summary of the Financial Education Program}

\begin{tabular}{|c|c|c|}
\hline Module & Topic & Activity \\
\hline \multirow[t]{10}{*}{ Shopping } & Introduction & Brainstorming: words associated with "shopping" \\
\hline & Discussion of shopping criteria & (a) Discussion: what did students buy last? \\
\hline & & Was it something they "needed" or "wanted"? \\
\hline & & (b) Comic strip: an adolescent receives money from his mother \\
\hline & & and spends it on unplanned expenses (chips and chocolate). \\
\hline & Advertising & (a) Discussion: where do you see ads? Which instruments are used \\
\hline & & in advertising (emotions, logos, etc.)? \\
\hline & & (b) Typical messages in ads \\
\hline & Buying a smartphone & (a) Discussion: what shopping criteria do you use? \\
\hline & & (b) Roleplay: adolescent wants to buy a smartphone, discussion \\
\hline \multicolumn{2}{|c|}{ Tips for students } & (1) Prioritize when making spending choices \\
\hline & & (2) Be critical about advertising \\
\hline & & (3) Think about which criteria are important for you before buying \\
\hline & & (4) Compare different options before buying \\
\hline \multirow[t]{7}{*}{ Planning } & Introduction & Brainstorming: words associated with "planning" \\
\hline & Different kinds of plans & $\begin{array}{l}\text { Exercise: linking different types of plans (e.g. school schedule) } \\
\text { to their purposes }\end{array}$ \\
\hline & Financial planning & (a) Discussion: why plan your expenses and income? \\
\hline & & (b) Discussion: where does your money come from and \\
\hline & & what do you spend it on? \\
\hline & & (c) Case study: Felix wants to buy a motorcycle; help him \\
\hline & & planning expenses, and discuss why Felix should not take on debt \\
\hline \multicolumn{2}{|c|}{ Tips for students } & (1) Just as with other plans, you can plan your finances \\
\hline & & (2) Have an overview of your income and expenses \\
\hline & & (3) A plan can help you reach your goals \\
\hline & & (4) Do not spend more money than you have \\
\hline & & (5) Purchases of durables can have running costs \\
\hline \multirow[t]{9}{*}{ Saving } & Introduction & Brainstorming: words associated with "saving" \\
\hline & Saving money & (a) Discussion: what do you do with money? \\
\hline & & (b) Discussion: how can you save money to reach your savings goal? \\
\hline & & (c) Discussion: why there are different savings products \\
\hline & & (d) Comic strip: savings product choice by an adolescent \\
\hline & Risk, return, liquidity & (a) Discussion: trade-off between risk, return and liquidity \\
\hline & & (b) Case study: Paul (14 years old) receives money for his \\
\hline & & driving license (to be spent at 18), help him choose how to save it \\
\hline & Definition of savings products & Find the product that matches the definition \\
\hline \multirow{5}{*}{\multicolumn{2}{|c|}{ Tips for students }} & (1) Decide which is more important for you: return, risk or liquidity \\
\hline & & (2) Do not choose the first offer made to you \\
\hline & & (3) Do not believe that one savings product can achieve \\
\hline & & everything (high return, low risk and high liquidity) \\
\hline & & (4) Decide which savings product fits best your objective \\
\hline
\end{tabular}




\section{Experimental Design}

\subsection{Setting and Randomization}

The schools in our study pertain to the two lower tracks of the German high school system. Students in these two tracks typically continue with vocational training after graduation (rather than attending college). ${ }^{8}$ Dustmann (2004) shows that there is a strong association between family background (parents' education as well as occupational status) and childrens' school track.

The randomization of classes to the control and treatment group was implemented through a web interface designed by the research team. Schools in the treatment group were assigned to receive the training earlier in the school year, while schools in the control group were assigned to receive the program towards the end of the school year. Randomization occurred at the school level to avoid spillover effects. Randomization was stratified by city, across the cities of Berlin, Düsseldorf and Munich in Germany, such that differences in the educational systems in the different areas are orthogonal to the treatment allocation. Since we were bound by scheduling constraints, including that all participating schools receive the training by the end of the school year, the time between treatment and intertemporal choice task was between 4 and 10 weeks. We thus measure short- to medium-run effects of the program.

\subsection{Method}

The elicitation method used is the Convex Time Budget (CTB), developed by Andreoni and Sprenger (2012). This method asks individuals to allocate amounts of money to

\footnotetext{
${ }^{8}$ The school system in Germany has three types of high schools, starting as of age 10. These tracks comprise schools in which students pursue vocational training (Hauptschule, Sekundarschule, Mittelschule), combine both vocational training with the option of accessing university later on (Realschule, Gesamtschule, Werkrealschule) or focus on preparation for university studies (Gymnasium). All participating students in our study belong to the first two types of schools.
} 
two points in time. The payment received at the sooner point in time, $t$, is $x_{t}$; the amount received at a later point in time, $t+k$, is $x_{t+k}$. The delay between payments is $k$. The amounts $x_{t}$ and $x_{t+k}$ satisfy the budget constraint $(1+r) x_{t}+x_{t+k}=m$, where $1+r$ is the gross interest rate. The CTB method allows for inner choices, i.e. to allocate payments to both payment dates, in addition to corner solutions, i.e. allocation of payment to a single payment date.

We elicit choices using three different combinations of $t$ and $t+k$; the tasks for each of these combinations are presented on a separate decision sheet. The first sheet offers payments immediately after the CTB $(t=0$, "today") and three weeks later, i.e., the delay is $k=3$ weeks. The second sheet offers payments today and six weeks later, i.e., the delay is $k=6$ weeks. The last sheet offers payments in three and in six weeks, i.e., the delay between payments is $k=3$ weeks but there is also a "front-end delay" as $t>0$. On each decision sheet, seven budget constraints - i.e., seven different interest rates - were presented to students, where the budget $m$ was 6 Euro. Going from top to bottom, the price for the sooner payment increases. An overview of the design is displayed in Table $2 .^{9}$

Table 2: Elicitation of time preferences - Design

\begin{tabular}{cccc}
\hline Decision sheet & Sooner payment $(t)$ & Later payment & Delay $(k)$ \\
\hline$(1)$ & Today & In 3 weeks & 3 weeks \\
$(2)$ & Today & In 6 weeks & 6 weeks \\
$(3)$ & In 3 weeks & In 6 weeks & 3 weeks \\
\hline
\end{tabular}

Note: Within each decision sheet seven decisions were elicited with the following gross interest rates $(1+r): 1.00,1.025,1.05,1.08,1.18,1.33$ and 2.00 , on the budget constraint $(1+r) x_{t}+x_{t+k}=m$.

We adapt the elicitation task to ensure that adolescents understands it. Andreoni and Sprenger (2012) offer a choice set with 100 choices within each budget. In a

\footnotetext{
${ }^{9}$ For example, for a delay of three weeks, the effective yearly interest rate, assuming quarterly compounding, ranges from $0 \%$, for gross rate 1.00 , to $752.9 \%$, for gross rate 1.18 , and goes up to $27128 \%$, for gross rate 2.00 . We chose to allow for high interest rates to capture variation in choice.
} 
follow-up study, Andreoni, Kuhn and Sprenger (2013) limit the choice set to seven choices. Both studies were conducted among university students. To reduce complexity in our adolescent sample, we offer four combinations of sooner and later payments. In each choice situation, participants can either allocate $100 \%, 66.6 \%, 33.3 \%$ or $0 \%$ of the budget to the sooner point in time. To make the variation in the time horizons salient, color-coding was used for each point in time. Additionally, students saw a calendar at the top of each sheet on which the relevant payment dates were marked in the corresponding color. An example of a decision sheet is provided in Figure 1. We randomized the ordering of the three decision sheets across classes to balance any potential order effects.

\begin{tabular}{|c|c|c|c|c|c|c|c|c|c|c|c|c|c|}
\hline \multicolumn{14}{|c|}{ TODAY and 3 WEEKS from today } \\
\hline & \begin{tabular}{|l|l|}
1 & 2 \\
\end{tabular} & 3 & 4 & 5 & \begin{tabular}{|l|l|}
6 & 7 \\
\end{tabular} & 1 & 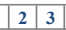 & 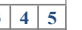 & & & & & \\
\hline & \begin{tabular}{|l|l}
8 & 9
\end{tabular} & 10 & 11 & 12 & $\begin{array}{lll}13 & 14 \\
\end{array}$ & 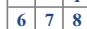 & \begin{tabular}{|l|l|}
9 & 10 \\
\end{tabular} & \begin{tabular}{|l|l|l|}
0 & 11 & 12 \\
\end{tabular} & \begin{tabular}{|l|l|}
3 & 4 \\
\end{tabular} & \begin{tabular}{|l|l|}
5 & 6 \\
\end{tabular} & \begin{tabular}{|l|l|}
7 & 8 \\
\end{tabular} & 9 & \\
\hline & $\begin{array}{|ll|}15 & 16\end{array}$ & 17 & 18 & 19 & 2021 & \begin{tabular}{|l|l|l|l|}
13 & 14 & 15 \\
\end{tabular} & \begin{tabular}{|l|l|l|}
5 & 16 & 17 \\
\end{tabular} & \begin{tabular}{|l|l|l|}
7 & 18 & 19 \\
\end{tabular} & \begin{tabular}{|l|l|}
10 & 11 \\
\end{tabular} & \begin{tabular}{|l|l|l|}
12 & 13 & 1 \\
\end{tabular} & \begin{tabular}{l|l|}
14 & 15 \\
\end{tabular} & \begin{tabular}{|l|l|}
5 & 16 \\
\end{tabular} & \\
\hline & $\begin{array}{|ll|}22 & 23 \\
\end{array}$ & 24 & 25 & 26 & \begin{tabular}{|l|}
2728 \\
\end{tabular} & \begin{tabular}{|l|l|l|l|}
20 & 21 & 22 \\
\end{tabular} & 2324 & 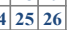 & \begin{tabular}{|l|l|}
17 & 18 \\
\end{tabular} & \begin{tabular}{l|l|l|}
19 & 20
\end{tabular} & \begin{tabular}{|l|l|}
21 & 22 \\
\end{tabular} & 223 & \\
\hline & \begin{tabular}{|l|l|}
29 & 30 \\
\end{tabular} & & & & & \begin{tabular}{|l|l|l|}
27 & 28 & 29 \\
\end{tabular} & \begin{tabular}{|l|l|l|}
9 & 30 & 31 \\
\end{tabular} & 1 & \begin{tabular}{|l|l|}
24 & 25 \\
\end{tabular} & \begin{tabular}{|l|l|l}
26 & 27 & 2 \\
\end{tabular} & \begin{tabular}{|l|l|}
28 & 29 \\
\end{tabular} & 930 & \\
\hline \multicolumn{14}{|c|}{$\begin{array}{l}\text { Choose in each decision (A1 to A7) the amounts that you want to receive with certainty today and in } 3 \text { weeks, } \\
\text { by crossing the corresponding box. Do not forget to cross only one box for each decision! }\end{array}$} \\
\hline \multirow{3}{*}{ A1. } & \multirow{3}{*}{\multicolumn{5}{|c|}{$\begin{array}{c}\text { Amount TODAY ... } \\
\text { AND amount in } 3 \text { WEEKS }\end{array}$}} & \multicolumn{2}{|l|}{$€ 6.00$} & \multicolumn{2}{|l|}{$€ 4.00$} & \multicolumn{3}{|l|}{$€ 2.00$} & $€ 0.00$ \\
\hline & & & & & & \multicolumn{2}{|l|}{$€ 0.00$} & $€ 2.00$ & & \multicolumn{3}{|l|}{$€ 4.00$} & $€ 6.00$ \\
\hline & & & & & & \multicolumn{2}{|l|}{$\square$} & $\square$ & & \multicolumn{3}{|l|}{$\square$} & $\square$ \\
\hline \multirow{3}{*}{ A2. } & \multirow{3}{*}{\multicolumn{5}{|c|}{$\begin{array}{c}\text { Amount TODAY ... } \\
\text { AND amount in } 3 \text { WEEKS }\end{array}$}} & \multicolumn{2}{|l|}{$€ 5.85$} & $€ 3.90$ & \multicolumn{4}{|c|}{$€ 1.95$} & $€ 0.00$ \\
\hline & & & & & & \multicolumn{2}{|l|}{$€ 0.00$} & $€ 2.00$ & & \multicolumn{3}{|c|}{$€ 4.00$} & $€ 6.00$ \\
\hline & & & & & & \multicolumn{2}{|l|}{$\square$} & $\square$ & & \multicolumn{3}{|l|}{$\square$} & $\square$ \\
\hline \multirow{3}{*}{ A3. } & \multirow{3}{*}{\multicolumn{5}{|c|}{$\begin{array}{c}\text { Amount TODAY ... } \\
\text { AND amount in } 3 \text { WEEKS }\end{array}$}} & \multicolumn{2}{|l|}{$€ 5.70$} & $€ 3.80$ & & \multicolumn{3}{|l|}{$€ 1.90$} & $€ 0.00$ \\
\hline & & & & & & \multicolumn{2}{|l|}{$€ 0.00$} & $€ 2.00$ & & \multicolumn{3}{|l|}{$€ 4.00$} & $€ 6.00$ \\
\hline & & & & & & $\square$ & & $\square$ & & $\square$ & & & $\square$ \\
\hline & Amoun & nt $T$ & OD & AI & Y ... & $€ 5.55$ & & $€ 3.70$ & & $€ 1.85$ & & & $€ 0.00$ \\
\hline A4. & $\boldsymbol{A N D}$ amoı & unt & in 3 & $3 w$ & VEEKS & $€ 0.00$ & & $€ 2.00$ & & $€ 4.00$ & & & $€ 6.00$ \\
\hline & & & & & & $\square$ & & $\square$ & & $\square$ & & & $\square$ \\
\hline & Amoun & $\overline{\text { nt } T}$ & $\overline{O D}$ & AI & $Y \ldots$ & 65.10 & & $€ 3.40$ & & $€ 1.70$ & & & $€ 0.00$ \\
\hline A 5. & $A N D$ amot & unt & in 3 & $3 w$ & NEEKS & $€ 0.00$ & & $€ 2.00$ & & $€ 4.00$ & & & $€ 6.00$ \\
\hline & & & & & & $\square$ & & $\square$ & & $\square$ & & & $\square$ \\
\hline & Amoun & nt $T$ & $\mathrm{OD}$ & AI & $\mathrm{Y} \ldots$ & $€ 4.50$ & & $€ 3.00$ & & $€ 1.50$ & & & $€ 0.00$ \\
\hline A6. & $A N D$ amou & unt & in 3 & $3 w$ & VEEKS & $€ 0.00$ & & $€ 2.00$ & & $€ 4.00$ & & & $€ 6.00$ \\
\hline & & & & & & $\square$ & & $\square$ & & $\square$ & & & $\square$ \\
\hline & Amoun & nt $T$ & TOD & AY & Y ... & $€ 3.00$ & & $€ 2.00$ & & $€ 1.00$ & & & $€ 0.00$ \\
\hline A7. & $A N D$ amol & unt & in 3 & $3 w$ & NEEKS & $€ 0.00$ & & $€ 2.00$ & & $€ 4.00$ & & & $€ 6.00$ \\
\hline & & & & & & $\square$ & & $\square$ & & $\square$ & & & $\square$ \\
\hline
\end{tabular}

Figure 1: Example of a decision sheet (translated from German) 


\subsection{Implementation of Payments}

We followed a number of procedures to ensure trust and to address issues of risk and transaction costs that typically arise when implementing delayed payments. All procedures were explained in the instructions before any decisions were taken by the adolescents.

Transaction costs. Students were given a "participation" fee of 2 Euro to thank them for their participation. They were informed that the participation fee would be split equally across both payment dates. Hence, independent of the exact choice of each student, she received always at least one Euro at each point in time.

Record of payments. After students made their $21(7 \times 3)$ choices, one decision was drawn for payment. The random draw was performed by one volunteer student for the entire class and this draw was noted on the classroom board. Subsequently, based on the student's choice and the decision drawn for payment, each student received a payment card that recorded her exact payments and payment dates. Hence, students did not have to remember when the future payment would occur and how much they would receive. The payment card also served as a written confirmation of each students' payment entitlement. The card format was designed to fit into students' wallets, and students were requested to keep it there. At the same time, each student wrote her name onto a payment list, which contained the payments she had chosen for the decision drawn for payment. This list was given to the teacher in the presence of the class. Both act as records for delayed payments and the payments list ensured that payments can be made even when individual payment cards are lost.

Delivery of payments. Payments were made in cash, in class, to each student individually. Immediate payments were made after the survey complementing the CTB experiment was completed, if today was drawn for payment. Delayed payments were 
made exactly three or six weeks later in class at the dates noted on the payment cards. The exact appointment for the future payment was discussed with the teacher and then announced in class. Our instructions clearly explained that we would come back into class once (or twice, depending on the draw) at the date(s) indicated on the calendars on their decision sheets and on payment cards to make the delayed payments. The teachers were present in class when we made this commitment. ${ }^{10}$ The same procedures were followed in the control and treatment group, and hence any issue of trust should be the same across the groups. The fact that we do not observe a treatment effect on the average allocation to the sooner payment date, as reported below, is in line with this.

Consent. Only students whose parents had consented to participate are included in the study. The consent forms provided to parents included the researchers' contact information, which the teacher also obtained. Almost all students (97\%) provided a signed consent form to participate in the study.

\subsection{Procedures}

In each session, the CTB task was conducted first, followed by a survey. The instructions for the CTB task were read aloud in front of the class. A copy of the instructions can be found in Appendix A. All class visits were conducted by the same two experimenters. One of them always presented the instructions in each session. Students were asked to complete four control questions before starting to provide their choices. These questions were designed to test the understanding of the task. Each student's answers were checked by the experimenters before she could start making her 21 choices.

The presentation of the instructions took on average 25 minutes, while students

\footnotetext{
${ }^{10}$ They were however kept uninformed about student choices, except for the one choice that was drawn for payment and recorded on the payment list.
} 
made their decisions in 5 to 10 minutes. After they finished with the CTB task, students were asked to complete a survey. We asked students for their gender and age, their math grade as well as three questions regarding their background. We elicited their household composition (i.e., who they live with), the language they speak at home and the amount of books at home. These are standard questions in the PISA survey (Frey et al., 2009). They are used to capture important family inputs into a student's education (for a review, see Hanuschek and Woessmann, 2011). Our survey also included four of Raven's progressive matrices (Raven, 1989), selected to measure heterogeneity in cognitive skills, based on a previous study in Germany by Heller et al. (1998). The survey also included several questions on financial knowledge and financial behavior. The impact of the training on standard financial literacy questions is similar to the findings in Lührmann, Serra-Garcia and Winter (2015), who study the effect of the program using survey questions in a non-experimental design. ${ }^{11}$ We also surveyed students regarding their allowance, spending and savings behavior.

In total sessions lasted between 45 and 60 minutes. In each city, all sessions were scheduled to take place during the same week, for both treatment and control groups. ${ }^{12}$

\subsection{Sample}

Our sample consists of 994 students from 55 classes in 25 schools (12 treatment, 13 control). We conducted the CTB task using pen and paper. When encoding the

\footnotetext{
${ }^{11}$ We observe an increase in knowledge about what stocks are, as measured by the question designed by van Rooij et al. (2011), which is a subject dealt with in the educational program. We do not find spillover effects to questions about interest compounding, the time value of money and risk diversification (based on standard financial literacy questions, see, e.g., Lusardi and Mitchell, 2014), concepts not taught in the program. Detailed results are available from the authors.

${ }^{12}$ To avoid any time effects, we scheduled the experiment to take place in each city during the same week in April. This was possible for 46 out of 55 classes. For a small group of nine classes the class was scheduled to be at a practical training out of school for the week, and hence we conducted the experiment 3 weeks later in eight classes and 6 weeks later for one class. We control for any potential time effects by adding a month dummy for April (as 46 out of 55 were scheduled in April) in our regression analysis.
} 
answers electronically, we found that 80 students provided one or multiple answers that could not be attributed a clear value. We present results for students who provided complete answers $\left(914,492\right.$ in control and 422 in treatment). ${ }^{13}$ The average age is 14.3 years and $39.8 \%$ of the students are female. Regarding the student's family situation, we find that a substantial share, $46.4 \%$, speak a language other than German at home. Also, $24 \%$ live with a single parent and $60.2 \%$ report having less than 25 books at home. Individual characteristics were balanced across treatment and control, as shown by the $t$-tests presented in Table 3, supporting that randomization worked. ${ }^{14}$

Since the unit of randomization was the school, we cluster standard errors at the school level throughout (Moulton, 1986).

Table 3: Individual characteristics in treatment and control group

\begin{tabular}{llcc}
\hline & Control & Treatment & $\begin{array}{c}\text { Treatment vs. Control } \\
t \text {-test }(p \text {-value })\end{array}$ \\
\hline Girl & $42.0 \%$ & $37.2 \%$ & 0.12 \\
Grade 8 & $50.6 \%$ & $52.1 \%$ & 0.92 \\
Cognition score & 0.756 & 0.718 & 0.67 \\
Math grade (relative) & 0.012 & 0.010 & 0.91 \\
Migrant background & $47.1 \%$ & $45.7 \%$ & 0.87 \\
Single parent & $23.4 \%$ & $25.1 \%$ & 0.67 \\
$<25$ books at home & $60.4 \%$ & $60.1 \%$ & 0.95 \\
\hline
\end{tabular}

Note: This table presents the mean of the individual characteristics by treatment and control. The third column reports the $p$-value of a $t$-test that the coefficient of the treatment dummy is equal to zero in a linear regression on each individual characteristic, using robust standard errors. Girl takes value 1 for female students, and grade 8 takes value 1 for students in that grade 8,0 if in grade 7 . Cognition score is the number of correct answers in 4 of Raven's progressive matrices. Math grade is defined relative to the average math grade in the class. A positive value indicates that the student performs better than the class average. Migrant background and single parent are dummy variables that take value 1 when the student speaks another language other than german at home and lives with a single parent, respectively. $<25$ books at home is a dummy that takes value one if the subject indicated the number of books at home was either 0-10 or 11-25 (below median), and zero if she indicated 26-100, 101-200, more than 200 books at home (above median).

\footnotetext{
${ }^{13}$ Results remain qualitatively the same if all students are included.

${ }^{14}$ Overall, nonresponse is very low, below $2.4 \%$ of the sample. The difference in nonresponse across treatment and control is not significant for any variables, except for books at home ( $t$-test, $p$-value $=0.04)$. Our results are robust to the inclusion of a dummy for nonresponse to this question.
} 


\section{Descriptive Results}

\subsection{Intertemporal Choices}

We first examine three important dimensions of intertemporal choice: i) the average allocation (budget share) to the sooner payment - a measure of impatience -, ii) the difference in the allocation to the sooner payment when the sooner payment is immediate - a hallmark of present bias -, and iii) the difference in the allocation to the sooner payment when the delay is increased - delay sensitivity. First, we do not observe a significant impact of the educational program on the average allocation to the sooner payment, as shown in Table $4 .{ }^{15}$

Second, the treatment group displays less present bias in their allocation choices than the control group. The extent of present bias is measured by comparing allocation choices when the sooner payment is immediate versus in the future. Controlling for interest rates and interaction effects, students in the control group increase their allocation by 5.85 percentage points when the sooner payment is immediate $(p=0.015)$, as shown in Table 4 . The effect of immediacy is reduced by 2.92 percentage points in the treatment group $(p=0.077)$. A similar result is obtained by comparing the proportion of present-biased choices. In the control group, on average, individuals make presentbiased choices in $22.2 \%$ of the cases. In the treatment group, this percentage is $19.9 \%$ (Mann-Whitney test, $p=0.0288) .{ }^{16}$

Third, we observe an increase in delay sensitivity among treated students. Models of intertemporal choice typically assume that individuals discount the future, i.e., they

\footnotetext{
${ }^{15}$ The estimates are obtained using interval regressions to account for the fact that students were offered four budget choices. Results are robust to using a simple OLS regression model.

${ }^{16}$ At the same time, the frequency of time consistent choices, i.e. choices that are the same when the sooner payment date is immediate and when it is delayed three weeks, increases from $58.2 \%$ to $61.5 \%$ (Mann-Whitney test, $p=0.0799$ ). In addition, there is a small non-significant decrease, from $19.7 \%$ to $18.6 \%$, in the percentage of choices in which the students allocate less money when payments are immediate (Mann-Whitney test, $p=0.1758$ ).
} 
Table 4: Determinants of allocation to sooner payment

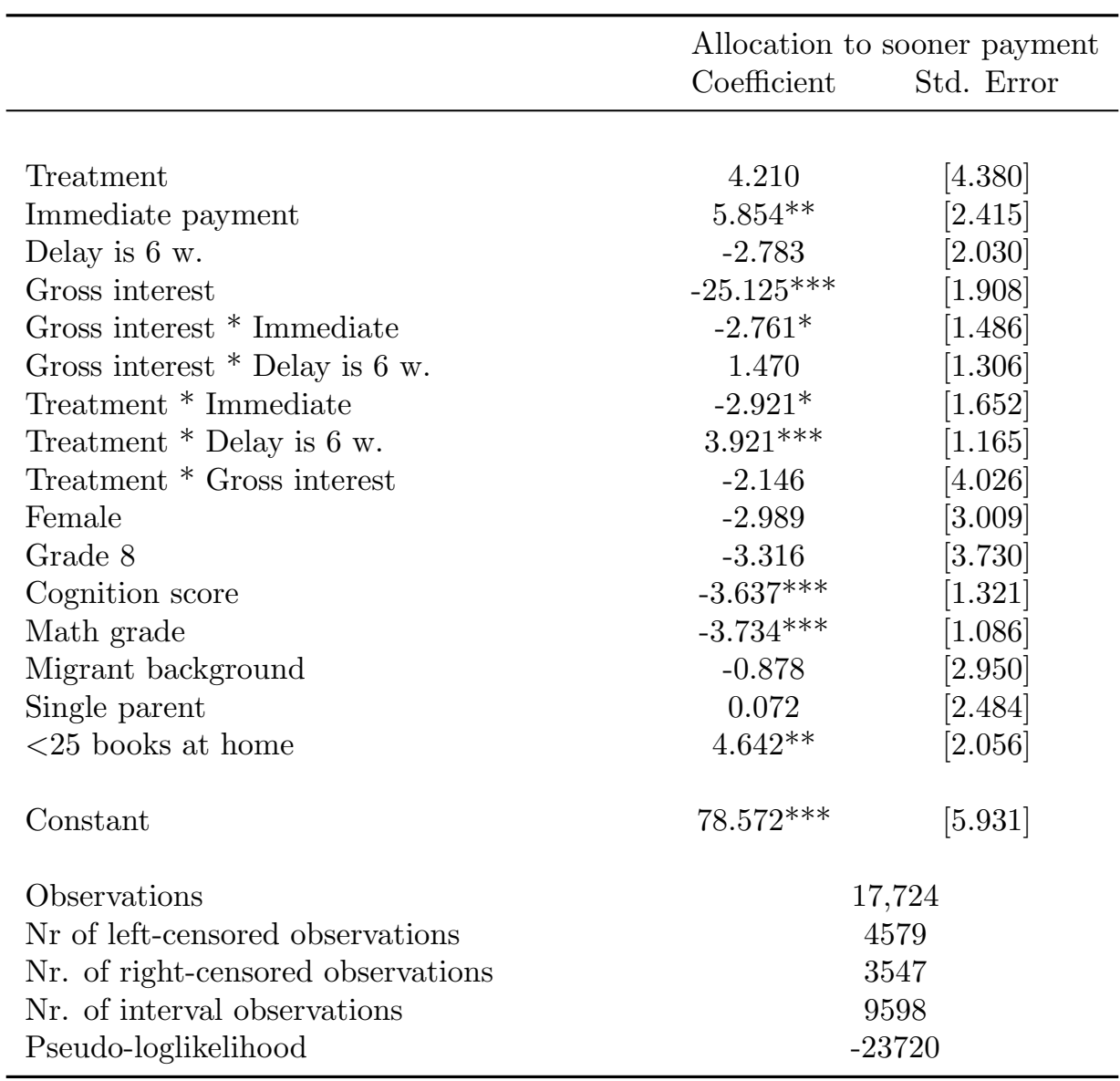

Note: Interval regression results. The dependent variable is the budget share allocated to the sooner payment date, ranging from 0 to 100 . Immediate payment is a dummy variable that takes the value 1 if the sooner payment occurred immediately after the students completed the task and survey. Delay is $6 \mathrm{w}$. is a dummy variable that takes the value 1 if the delay between the sooner and later payment was 6 weeks and not 3 weeks. Individual characteristics are defined as in Table 3. Month and location fixed effects are included in all regressions. Robust standard errors are shown, clustered at the school level (25 clusters). ***, **, * indicate significance at the 1,5 and 10 percent level, respectively.

prefer payments sooner ceteris paribus. This implies that allocations to the sooner payment are expected to increase as the delay between sooner and later payment dates increases. We find no increase in allocations to the sooner payment as delay increases in the control group, as shown in Table 4. With the treatment, delay sensitivity increases significantly $(p=0.001)$. 
The allocations chosen by the students vary with student characteristics in a similar way as found in previous results in studies of adolescents' intertemporal choice. For example, in line with Castillo et al. (2011) and Sutter et al. (2013), we find that students with higher math grades and cognition scores display more patience in their choices.

To sum up, we find that the educational program decreases present bias and increases delay sensitivity. A central question is the interpretation of such effects. As highlighted by Dean and Sautmann (2014) and Carvalho, Meier and Wang (2014), changes in intertemporal allocations could be due to changes in external consumption opportunities. The survey administered to students measured the monthly allowance of each student and the amount of spending in a typical month. We find no significant effects of the treatment on these two measures ( $t$-test from a regression with a treatment dummy and robust standard errors, $p=0.414$ and 0.489 , respectively). ${ }^{17}$ Thus, we find no changes in the external consumption opportunities of students across the treatment and control group, which could give rise to the treatment effects established in this section.

\subsection{Consistency and Corner Solutions}

In addition to the allocations chosen in the CTB task, we examine the consistency of choices with the law of demand, and the rate with which students choose a corner solution, i.e. allocate the entire budget to a single payment date. Consistency is measured as in Giné et al. (2012), by checking whether a weakly smaller allocation to the sooner payment is chosen as the interest rate increases. Such a choice is consistent with the law of demand. ${ }^{18}$ On average, $80.8 \%$ of choices in the control and $82.9 \%$ in the treatment

\footnotetext{
${ }^{17}$ The results reported in Table 4 and 5 (shown below) are also robust to including allowance or spending as controls.

${ }^{18}$ Precisely, within each of the three decision sheets, students made seven choices. A choice is consistent with the law of demand if the allocation to the sooner payment date decreases or stays
} 
group are consistent with the law of demand. These rates are very similar to those found by Gine et al. (2012) in individual interviews with farmers in Malawi (81\%) and by Carvalho, Meier and Wang (2014) in the American Life Panel (82\% before payday and $84 \%$ after payday). The educational program has a positive effect on consistency with the law of demand, as shown in Table 5, columns (1-2). In line with the idea that inconsistencies may reflect indifference between allocations, we observe an increase in consistency with the law of demand as the interest rate offered increases.

We also examine whether the program has an effect on the rate at which students choose corner solutions. While around $70 \%$ of the choices in Andreoni and Sprenger (2012) were corner solutions, we find that interior solutions predominate in our sample, with an average of $55.8 \%$ interior choices in the control group and $52 \%$ in the treatment group on average. Controlling for the characteristics of the budget available (e.g., gross interest rate) and individual characteristics, we find that the rate at which treated students choose corner solutions increases by 7 to 8 percentage points, as shown in Table 5, columns (3-4).

Since there is an increase in consistency with the law of demand among treated students, which occurs simultaneously with the changes in delay sensitivity and present bias, it is possible that treatment effects on the latter are confounded by the treatment effect on consistency with the law of demand. To address this problem in what follows, we estimate the time preference parameters implied by the allocation choices, using a model that allows for stochastic choices. This represents a methodological contribution to existing studies using the CBT task, where inconsistencies with the law of demand have thus far not been modeled. The structural estimation also allows for a clearer interpretation of the effects we observe, i.e. how an increase in delay sensitivity affects discount factor and how strong present bias is, compared to existing estimates in the

unchanged as the interest rate increases. By definition, the first choice in each sheet is excluded. Thus, the fraction of consistent choices with the law of demand is the sum of consistent choices over 18 . 
Table 5: Consistent choices and corner choices

\begin{tabular}{|c|c|c|c|c|}
\hline & \multicolumn{2}{|c|}{ Consistent choice } & $\begin{array}{l}(3) \\
\text { Corn }\end{array}$ & $\begin{array}{c}(4) \\
\text { choice }\end{array}$ \\
\hline \multirow[t]{2}{*}{ Treatment } & $0.053^{*}$ & $0.054^{*}$ & $0.068^{*}$ & $0.078^{* * *}$ \\
\hline & {$[0.030]$} & {$[0.028]$} & {$[0.040]$} & {$[0.029]$} \\
\hline \multirow[t]{2}{*}{ Immediate payment } & 0.004 & 0.012 & $0.034^{*}$ & $0.047^{* *}$ \\
\hline & {$[0.023]$} & {$[0.020]$} & {$[0.019]$} & {$[0.020]$} \\
\hline \multirow[t]{2}{*}{ Delay $=6$ weeks } & 0.008 & 0.006 & -0.007 & -0.023 \\
\hline & {$[0.025]$} & {$[0.024]$} & {$[0.027]$} & {$[0.026]$} \\
\hline \multirow[t]{2}{*}{ Gross interest } & $0.045^{* * *}$ & $0.052^{* * *}$ & 0.009 & 0.015 \\
\hline & {$[0.017]$} & {$[0.017]$} & {$[0.014]$} & {$[0.013]$} \\
\hline \multirow[t]{2}{*}{ Gross interest $*$ Immediate } & 0.003 & -0.004 & -0.004 & -0.016 \\
\hline & {$[0.016]$} & {$[0.015]$} & {$[0.014]$} & {$[0.016]$} \\
\hline \multirow[t]{2}{*}{ Gross interest $*$ Delay is $6 \mathrm{w}$. } & -0.004 & -0.002 & 0.003 & 0.015 \\
\hline & {$[0.020]$} & {$[0.020]$} & {$[0.019]$} & [0.019] \\
\hline \multirow[t]{2}{*}{ Treatment $*$ Immediate } & -0.001 & 0.001 & -0.013 & -0.016 \\
\hline & {$[0.010]$} & {$[0.011]$} & {$[0.013]$} & [0.012] \\
\hline \multirow[t]{2}{*}{ Treatment $*$ Delay is $6 \mathrm{w}$. } & -0.014 & $-0.013^{*}$ & 0.010 & 0.011 \\
\hline & {$[0.009]$} & {$[0.007]$} & {$[0.013]$} & {$[0.013]$} \\
\hline \multirow[t]{2}{*}{ Treatment $*$ Gross interest } & -0.020 & -0.022 & -0.018 & -0.026 \\
\hline & {$[0.019]$} & {$[0.020]$} & {$[0.017]$} & {$[0.016]$} \\
\hline Add. Controls & No & Yes & No & Yes \\
\hline Observations & 16,452 & 15,192 & 19,194 & 17,724 \\
\hline
\end{tabular}

Note: Probit regression, marginal effects shown, with robust standard errors clustered at the school level (25 clusters). Consistent choice takes value 1 if the choice is consistent with the law of demand, 0 otherwise. Corner choice takes value 1 if the choice was to allocate 0 or $100 \%$ of the budget to the sooner payment date. Add. Controls is Yes when individual characteristics, defined as in Table 3 (gender, grade, cognition score, relative math grade, migrant background, single parent and books at home). The detailed table including the coefficient estimates for individual characteristics is presented in Appendix C. Columns (2) and (4) also include location and month fixed effects. ***, **, * indicate significance at the 1,5 and 10 percent level, respectively.

\section{literature.}




\section{$5 \quad$ Estimation of Time Preferences}

\subsection{Theoretical Framework and Empirical Model}

Following Andreoni and Sprenger (2012), we assume a time separable CRRA utility

function within the $\beta-\delta$ model of quasi-hyperbolic discounting (e.g., Laibson, 1997),

$$
U\left(x_{t}, x_{t+k}\right)=x_{t}^{\alpha}+\beta^{I_{t=0}} \delta^{k} x_{t+k}^{\alpha}
$$

where the individual receives monetary amounts $x_{t}$ and $x_{t+k}$ at times $t$ and $t+k$, and $I_{t=0}$ is an indicator variable that takes value one if payments are immediate. The parameter $\beta$ is the present bias parameter, $\delta$ is the discount factor and $\alpha$ measures the curvature in the CRRA utility function. Individuals maximize utility subject to the budget constraint, $(1+r) x_{t}+x_{t+k}=m$.

To estimate these preference parameters we allow choices to be stochastic. The details are presented in Appendix B. Briefly, we extend the standard interval data model (Wooldridge, 2001, p. 509), and introduce trembling-hand and Fechner errors. Introducing a trembling-hand error $\omega$ (Harless and Camerer, 1994) allows for a probability $\omega$ that a random choice is made in a given decision. Fechner errors allow that errors may be made when evaluating the distance between the optimal ratio of consumption and the available ratio. A larger Fechner error parameter, $\tau$, implies that this distance is given less weight and hence that errors are more likely (von Gaudecker, van Soest and Wengström, 2011). Because of the discrete nature of the data, the CRRA parameter $\alpha$ can only be jointly identified with the Fechner error, $\tau$, and thus this estimate is unlikely to be accurate (see, also, Andreoni, Kuhn and Sprenger, 2013). As a robustness check, we also estimate preference parameters using a different model of stochastic decision 
making, based on Luce (1959), and adopted by Andersen et al. (2008). ${ }^{19,20}$

\subsection{Aggregate Parameters}

We begin by presenting estimates obtained from the treatment and control groups, assuming homogenous preference parameters within each group. Columns (1) and (2) of Table 6 display estimated parameters, for the control and treatment group, respectively The estimated $\beta$ is 0.928 in the control group, which is significantly different from one $\left(\chi^{2}\right.$-test, $\left.p<0.01\right)$. In contrast, in the treatment group, $\hat{\beta}$ is 0.994 , and not significantly different from one $\left(\chi^{2}\right.$-test, $\left.p=0.695\right)$. The estimated $\beta$ increases in the treatment group ( $t$-test, $p=0.019$ ). Consistent with our previous result, the treatment leads to a statistically significant decrease in present bias. Columns (3) and (4) of Table 6 display qualitatively similar results using the Luce probabilistic choice model.

The estimated value of $\beta$ in the control group, between 0.928 and 0.943 , indicates moderate present bias. It is slightly larger than the value of $\beta$ for effort choices in Augenblick et al. (2013), which is between 0.877 and 0.900. By contrast, the estimated $\beta$ in the treatment group is similar to that estimated for money in Augenblick et al. (2013), which is between 0.974 and 0.988 .

The estimated daily discount factor is between 0.989 and 0.997 , in line with previous studies (e.g., Augenblick et al., 2013). There is a small, statistically significant decrease in the discount factor in the treatment group ( $t$-test, $p=0.046)$. It is in line with the increased delay sensitivity, found at the descriptive level, since the discount factor is

\footnotetext{
${ }^{19}$ We assume Fechner errors to be homogeneous within each group and allow trembling-hand errors to be school-specific. The trembling-hand error should be estimated at the individual level, such that it accounts for noise specific to the decisions of an individual. We follow this approach in the next subsection. In this specification we allow it to vary at the school level, where there is a substantial degree of variation. Results remain robust to estimating a single trembling-hand error.

${ }^{20}$ In Appendix $\mathrm{C}$ we also present further robustness checks of our results, including the estimation of time preference parameters when we assume the trembling-hand error $\omega$ is homogeneous within the treatment and control group, respectively, when do not allow for Fechner errors, and using the non-linear least squares approach in Andreoni and Sprenger (2012).
} 
ters. It also captures potentially important heterogeneity in estimated time preference parameters (Gollier and Zeckhauser, 2005).

Table 7 displays estimates of the present bias parameter $\left(\hat{\beta}_{i}\right)$, the discount factor $\left(\hat{\delta}_{i}\right)$ and the trembling-hand error $\left(\hat{\omega}_{i}\right)$, at the individual level. Estimates are obtained for 815 students, 444 in the control and 371 in treatment group, out of 914 in the sample. ${ }^{21,22}$

Table 7: Descriptive statistics for the estimated individual parameters

\begin{tabular}{lccccc}
\hline & & $5^{\text {th }}$ & $25^{\text {th }}$ & $75^{\text {th }}$ & $95^{\text {th }}$ \\
& Median & Percentile & Percentile & Percentile & Percentile \\
\hline Control & & & & & \\
Present bias parameter $\left(\hat{\beta}_{i}\right)$ & 1.000 & 0.440 & 0.751 & 1.155 & 2.627 \\
Discount factor $\left(\hat{\delta}_{i}\right)$ & 1.002 & 0.962 & 0.997 & 1.018 & 1.056 \\
Trembling-hand error $\left(\hat{\omega}_{i}\right)$ & 0.149 & 0.000 & 0.000 & 0.358 & 0.585 \\
& & & & & \\
Treatment & & & & \\
Present bias parameter $\left(\hat{\beta}_{i}\right)$ & 0.998 & 0.464 & 0.782 & 1.140 & 2.075 \\
Discount factor $\left(\hat{\delta}_{i}\right)$ & 1.003 & 0.961 & 0.995 & 1.014 & 1.108 \\
Trembling-hand error $\left(\hat{\omega}_{i}\right)$ & 0.000 & 0.000 & 0.000 & 0.189 & 0.581 \\
\hline
\end{tabular}

Note: The subscript $i$ indicates individual $i . N=815$.

Table 8 displays the treatment effects on individual parameters. We first examine whether the treatment increases the share of time-consistent students, those with $0.99<$ $\hat{\beta}_{i}<1.01$, as defined in Augenblick, Niederle and Sprenger (2013). We find a significant increase in the share of time-consistent students in the treatment group, of between 8

\footnotetext{
${ }^{21}$ We cannot estimate the parameters for 77 of the subjects, since their choices exhibit zero variance across allocation choices. The estimation does not converge for six subjects, and extreme values of $\beta$, smaller than 0.01 and larger than 9.6, are obtained for 18 subjects (upper and bottom 1\%). There is no difference in the distribution of subjects across treatment and control group ( $\chi^{2}$ test, $p=0.559$, for subjects exhibiting zero variance, and $p=0.199$, for extreme values of $\beta$.)

${ }^{22}$ The estimated individual parameters correlate significantly with the underlying choices, as one would expect. The Spearman rank correlation coefficient between $\hat{\beta}_{i}$ and the difference between the share allocated to the sooner date when the sooner date is immediate compared to delayed is $\rho=$ $-0.1846(p<0.01)$. The Spearman rank correlation coefficient between $\hat{\delta}_{i}$ and share allocated to the sooner point in time is $-0.0594(p=0.09)$, and between the share of choices consistent with the law of demand and $\hat{\omega}_{i}$ is $-0.1448(p<0.01)$. Detailed results for the estimates of $\hat{\alpha}_{i}$ and $\hat{\tau}_{i}$ are presented in Appendix C.
} 
and 10 percentage points. We also estimate a multivariate multiple regression model to examine the treatment effect on the jointly determined parameters. The results reveal an insignificant decrease in $\hat{\beta}_{i}$. This result, together with the increase in time consistency, suggests that, when individual heterogeneity is allowed, both present bias and future bias may have decreased. The data indeed reveal a decrease in the share of strongly present biased individuals, with $\hat{\beta}_{i}<0.6$ ( $\chi^{2}$-test, $\left.p=0.07\right)$, but no significant decrease in the share of individuals that are classified as present biased, i.e. $\hat{\beta}_{i}<0.99$. At the same time, we find no evidence of a significant decrease in the share of strongly future biased individuals, with $\hat{\beta}_{i}>1.4$, but we find a decrease in the share of future biased individuals, with $\hat{\beta}_{i}>1.01\left(\chi^{2}\right.$-test, $\left.p<0.01\right)$. This could in turn explain the decrease in the aggregate level of present bias.

Table 8: Treatment effect on time consistency and individual-level time preference parameters

\begin{tabular}{|c|c|c|c|c|c|c|c|c|}
\hline & \multicolumn{2}{|c|}{$\begin{array}{c}\text { Time } \\
\text { consistency }\end{array}$} & \multicolumn{2}{|c|}{$\begin{array}{l}\text { Present bias parameter } \\
\qquad\left(\hat{\beta}_{i}\right)\end{array}$} & \multicolumn{2}{|c|}{$\begin{array}{l}\text { Discount factor } \\
\left(\hat{\delta}_{i}\right)\end{array}$} & \multicolumn{2}{|c|}{$\begin{array}{l}\text { Trembling-hand error } \\
\qquad\left(\hat{\omega}_{i}\right)\end{array}$} \\
\hline Treatment & $\begin{array}{l}0.084^{*} \\
{[0.046]}\end{array}$ & $\begin{array}{r}0.103^{* * *} \\
{[0.038]}\end{array}$ & $\begin{array}{r}-0.040 \\
{[0.051]} \\
1.106^{* * *} \\
{[0.035]}\end{array}$ & $\begin{array}{r}-0.033 \\
{[0.057]} \\
1.017^{* * *} \\
{[0.139]}\end{array}$ & $\begin{array}{r}0.006 \\
{[0.006]} \\
1.007^{* * *} \\
{[0.004]}\end{array}$ & $\begin{array}{r}0.009 \\
{[0.007]} \\
0.969^{* * *} \\
{[0.017]}\end{array}$ & $\begin{array}{r}-0.071 * * * \\
{[0.014]} \\
0.192^{* * *} \\
{[0.009]}\end{array}$ & $\begin{array}{r}-0.073^{* * *} \\
{[0.015]} \\
0.258^{* * *} \\
{[0.037]}\end{array}$ \\
\hline $\begin{array}{l}\text { Add. controls } \\
\text { Observations } \\
\text { Adj. R-squared }\end{array}$ & $\begin{array}{r}\text { No } \\
815\end{array}$ & $\begin{array}{l}\text { Yes } \\
749\end{array}$ & $\begin{array}{r}\text { No } \\
815 \\
0.001\end{array}$ & $\begin{array}{r}\text { Yes } \\
749 \\
0.037\end{array}$ & $\begin{array}{r}\text { No } \\
815 \\
0.001\end{array}$ & $\begin{array}{r}\text { Yes } \\
749 \\
0.014\end{array}$ & $\begin{array}{r}\text { No } \\
815 \\
0.013\end{array}$ & $\begin{array}{r}\text { Yes } \\
749 \\
0.047\end{array}$ \\
\hline
\end{tabular}

Note: Columns (1-2) reports the marginal effects of a probit model on the likelihood that an individual is time-consistent, i.e., $\hat{\beta}_{i}$ falls within $0.99<\hat{\beta}_{i}<1.01$. Columns $(3-6)$ report multivariate regression results on all estimated time preference parameters. Treatment is a dummy variable that takes value 1 if the student participated in the education program. Add. Controls is Yes when individual characteristics, defined as in Table 3 (gender, grade, cognition score, relative math grade, migrant background, single parent and books at home). The detailed table including the coefficient estimates for individual characteristics is presented in Appendix C. Columns (2), (4), (6) and (8) also include location and month fixed effects. Robust standard errors, clustered at the school level, are computed. $* * *, * *, *$ indicate significance at the 1,5 and 10 percent level, respectively.

Table 8 reveals that the treatment did not affect individual discount factors $\left(\hat{\delta}_{i}\right)$. The treatment strongly decreased the estimated trembling-hand error $\left(\hat{\omega}_{i}\right)$. This result 
is in line with the increase in the share of choices consistent with the law of demand found in the descriptive analysis.

\subsection{Individual Parameters and External Savings Behavior}

The overall pattern of results indicates that the program had a strong and robust effect on consistency with the law of demand. This suggests that a first impact of the educational program was to improve understanding of intertemporal tradeoffs. Consistency in choices is economically important, as Choi et al. (2014) show in a risk preference elicitation task. They find consistency, defined in terms of the Generalized Axiom of Revealed Preference (GARP), is correlated with wealth accumulation and other financial outcomes.

A second result that emerges is that the treatment induces an increase in time consistency. The absence of changes in the income or spending of students across treatment and control suggests that changes in external consumption opportunities cannot explain the observed changes in intertemporal choice. We consider two alternative explanations in what follows. First, the estimated present bias may not capture any underlying feature of students' time preferences. In that case, we would expect this estimated parameter to be uncorrelated with field behaviors, such as savings. We explore this hypothesis by relating the estimated parameters to several field behaviors reported in the survey conducted after the CTB task. We consider savings behavior, i.e. whether the student saves and, if so, how much. We additionally study self-reported impulsivity measures when shopping, based on Rook and Fisher (1995) and Valence et al. (1988). The measure is the average answer to four statements: "I buy impulsively"; "before I buy something, I consider carefully whether I can afford it" (reverse coded); "before I buy something important, I compare prices in the Internet or several shops" (reverse coded); and, "sometimes I regret having bought something new". The answers were 
given on a 5-item Likert scale, 1-strongly disagree to 5-strongly agree. We also include a measure of efficacy at achieving savings goals. This measure is the average answer to two statements: "when I plan to buy something, I manage to save for it"; "I am good at reaching my saving goals". The answers were provided on the same 5-item Likert scale.

Table 9 displays the relationship between the estimated present bias parameter, $\hat{\beta}_{i}$, and these field behaviors. A higher $\hat{\beta}_{i}$, implying lower present bias, is related to increased savings amounts and a higher self-reported efficacy at achieving savings goals. The correlation between $\hat{\beta}_{i}$ and impulsivity is also of the expected sign. Additionally, $\hat{\delta}_{i}$ is related to savings amount as expected. Overall, these correlations suggest that the estimated time preference parameters are informative of students' behavior.

The second explanation is that the treatment may have changed how students view time-dated experimental payments, especially how they view them in relation to other sources of money. Adolescents in our sample receive an allowance from their parents, of 34.2 Euro per month on average. Since students learn to set up a budget that considers all sources of income and expenditure, treated students may have considered the offered time-dates experimental payments as part of their overall budget. The estimates in Table 9 for the interaction between $\hat{\beta}_{i}$ and the treatment provide suggestive evidence that the relationship between estimated parameters and field behaviors weakens with the treatment. In particular, we observe a marginally significant decrease in the relationship between $\hat{\beta}_{i}$ and savings amount in the treatment group. The same sign is obtained for $\hat{\delta}_{i}$, though it is not significant. For efficacy at achieving savings goals, we also observe a decrease in the relationship between $\hat{\delta}_{i}$ and efficacy at achieving savings goals, which is positive though not significant in the control group. Overall, this suggests that in the treatment group choices may have become less informative about preferences. 
Table 9: Estimated parameters and field behaviors

\begin{tabular}{|c|c|c|c|c|}
\hline & $\begin{array}{c}(1) \\
\text { Save }(0 / 1)\end{array}$ & $\begin{array}{c}(2) \\
\text { If save }=1 \\
\ln (\text { save })\end{array}$ & $\begin{array}{c}(3) \\
\text { Impulsivity }\end{array}$ & $\begin{array}{c}(4) \\
\text { Achieve } \\
\text { saving goals }\end{array}$ \\
\hline Present bias $\left(\hat{\beta}_{i}\right)$ & $\begin{array}{r}0.092 \\
{[0.099]}\end{array}$ & $\begin{array}{r}0.283^{* * *} \\
{[0.064]}\end{array}$ & $\begin{array}{l}-0.069 \\
{[0.052]}\end{array}$ & $\begin{array}{r}0.113^{* *} \\
{[0.052]}\end{array}$ \\
\hline Discount factor $\left(\hat{\delta}_{i}\right)$ & $\begin{array}{l}-0.039 \\
{[2.537]}\end{array}$ & $\begin{array}{r}4.016^{* *} \\
{[1.767]}\end{array}$ & $\begin{array}{r}0.938 \\
{[1.743]}\end{array}$ & $\begin{array}{r}1.964 \\
{[1.150]}\end{array}$ \\
\hline Trembling-hand error $\left(\hat{\omega}_{i}\right)$ & $\begin{array}{r}0.149 \\
{[0.308]}\end{array}$ & $\begin{array}{l}-0.070 \\
{[0.421]}\end{array}$ & $\begin{array}{r}0.112 \\
{[0.294]}\end{array}$ & $\begin{array}{r}0.446 \\
{[0.268]}\end{array}$ \\
\hline Treatment & $\begin{array}{r}0.299 \\
{[2.595]}\end{array}$ & $\begin{array}{r}3.316 \\
{[2.186]}\end{array}$ & $\begin{array}{r}0.685 \\
{[1.850]}\end{array}$ & $\begin{array}{r}2.833^{* *} \\
{[1.253]}\end{array}$ \\
\hline$\hat{\beta}_{i} *$ treatment & $\begin{array}{r}0.023 \\
{[0.124]}\end{array}$ & $\begin{array}{r}-0.227^{*} \\
{[0.116]}\end{array}$ & $\begin{array}{r}0.109 \\
{[0.071]}\end{array}$ & $\begin{array}{l}-0.055 \\
{[0.098]}\end{array}$ \\
\hline$\hat{\delta}_{i} *$ treatment & $\begin{array}{l}-0.396 \\
{[2.533]}\end{array}$ & $\begin{array}{l}-3.098 \\
{[2.185]}\end{array}$ & $\begin{array}{l}-0.845 \\
{[1.797]}\end{array}$ & $\begin{array}{r}-2.649^{* *} \\
{[1.196]}\end{array}$ \\
\hline$\hat{\omega}_{i} *$ treatment & $\begin{array}{l}-0.081 \\
{[0.428]}\end{array}$ & $\begin{array}{r}-0.594 \\
{[0.507]}\end{array}$ & $\begin{array}{r}0.206 \\
{[0.422]}\end{array}$ & $\begin{array}{l}-0.410 \\
{[0.371]}\end{array}$ \\
\hline Constant & $\begin{array}{r}0.037 \\
{[2.604]}\end{array}$ & $\begin{array}{c}-0.583 \\
{[1.856]}\end{array}$ & $\begin{array}{c}-0.885 \\
{[1.775]}\end{array}$ & $\begin{array}{c}-2.378^{*} \\
{[1.214]}\end{array}$ \\
\hline $\begin{array}{l}\text { Observations } \\
\text { Adj. R-squared }\end{array}$ & 749 & $\begin{array}{r}371 \\
0.079\end{array}$ & $\begin{array}{r}730 \\
0.030\end{array}$ & $\begin{array}{r}734 \\
0.080\end{array}$ \\
\hline
\end{tabular}

Note: Column (1) reports estimated marginal effects of a probit model on the likelihood that an individual saves. Columns (2-4) report OLS regression results on the natural logarithm of savings, conditional on savings, self-reported impulsivity and efficacy at achieving saving goals. The latter two measures are standardized. The parameters $\hat{\beta}_{i}, \hat{\delta}_{i}$ and $\hat{\omega}_{i}$ are obtained through the joint estimation of time preference parameters as outlined in Section 5.1. The table includes individual characteristics (gender, grade, cognition score, relative math grade, migrant background, single parent and books at home) as controls. The detailed table including the coefficient estimates for individual characteristics is presented in Appendix C. All specifications include location and month fixed effects. Robust standard errors, clustered at the school level, are computed. ***, **,

* indicate significance at the 1,5 and 10 percent level, respectively.

\section{Conclusion}

This paper examines the effect of a financial education intervention on intertemporal choices in adolescence. Following random assignment to the intervention, we measure intertemporal choices using a controlled and incentivized experiment offering a variety of time-dated payments, across different time horizons. 
The program leads to a significant increase in consistency of choices with the law of demand. This suggests that a first effect of the program was to enhance the understanding of intertemporal tradeoffs. Further, treated students do not exhibit present bias on average. They are also more likely to allocate the entire budget to a single payment date, and their choices in the task are less informative of their external savings behavior. Further, the treatment does not increase savings, allowance or spending. Taken together, these results suggest that treated students exhibit a behavior that is more consistent with arbitrage and broad bracketing of their decisions. In other words, the educational program appears to have changed the way students view the experimental payments offered to them.

These results provide a new perspective regarding the impact of financial education. Most financial education programs, including the one we study, discuss savings choices extensively, and hence most studies that investigate the impact of financial education on behavior focus on outcomes such as saving. Our results suggest that short financial education programs may change how individuals at a young age view intertemporal tradeoffs, enhancing both their understanding and broadening the set of alternatives that they consider when making such choices.

\section{References}

Afriat, S., 1972. "Efficiency estimates of production functions." International Economic Review, 8, 568-598.

Andersen, S., G. W. Harrison, M. I. Lau, and E. E. Rutstrom, 2008. "Eliciting risk and time preferences." Econometrica, 76 (3), 583-618.

Andreoni, J. and C. Sprenger, 2012. "Estimating time preferences from convex time budgets." American Economic Review, 102 (7), 3333-3356. 
Andreoni, J., M. Kuhn, and C. Sprenger, 2013. "On measuring time preferences." NBER Working Paper No. 19392.

Augenblick, N., M. Niederle, and C. Sprenger, 2013. "Working over time: Dynamic inconsistency in real effort tasks." NBER Working Paper No. 18734.

Becchetti, L., S. Caiazza, and D. Coviello, 2013. "Financial education and investment attitudes in high schools: evidence from a randomized experiment." Applied Financial Economics, 23 (10), 817-836.

Becker, G. S. and C. B. Mulligan, 1997. "The endogenous determination of time preference." Quarterly Journal of Economics, 112 (3), 729-758.

Berry, J., D. Karlan, and M. Pradhan, 2015. "The Impact of Financial Education for Youth in Ghana" NBER Working Paper 21068.

Bettinger, E. and R. Slonim, 2007. "Patience among children." Journal of Public Economics, 91, 343-363.

Bruhn, M., L. de Souza Leao, A. Legovini, R. Marchetti, and B. Zia, 2013. "Financial education and behavior formation: Large scale experimental evidence from Brazil." World Bank Policy Research Working Paper 6723.

Carvalho, L. S., S. Prina, and J. Sydnor, 2014. "The effect of saving on risk attitudes and intertemporal choices." Unpublished manuscript.

Carvalho, L. S., S. Meier, and S. W. Wang, 2014. "Poverty and economic decisionmaking: Evidence from changes in financial resources at payday." Unpublished manuscript.

Castillo, M., P. Ferraro, J. Jordan, and R. Petrie, 2011. "The today and tomorrow of kids: Time preferences and educational outcomes of children." Journal of Public Economics, 95, 1377-1385. 
Chabris, C. F., D. Laibson, and J. P. Schuldt, 2008. "Intertemporal choice." In S. Durlauf and L. Blume (eds.), The New Palgrave Dictionary of Economics (2nd ed.), London: Palgrave Macmillan.

Chabris C. F., D. Laibson, C. L. Morris, J. P. Schuldt, D. Taubinsky, 2008. "Individual laboratory-measured discount rates predict field behavior." Journal of Risk and Uncertainty, 37, 237-269.

Choi, S., S. Kariv, W. Müller, and D. Silverman, 2014. "Who is (more) rational?" American Economic Review, 104 (6), 1518-50.

CFPB, 2013. "Navigating the market: A comparison of spending on financial education and financial marketing."

Coller, M. and M. B. Williams, 1999. "Eliciting individual discount rates." Experimental Economics 2, 107-127.

Cubitt, R. P. and D. Read, 2007. "Can Intertemporal Choice Experiments Elicit Preferences for Consumption." Experimental Economics 10 (4), 369-389.

Dean, M. and A. Sautmann, 2014. "Credit Constraints and The Measurement of Time Preferences." Working paper.

Dustmann, C., 2004. "Parental background, secondary school track choice, and wages." Oxford Economic Papers, 56 (2), 209-230.

Frederick, S., G. Loewenstein, and T. O'Donoghue, 2002. "Time discounting and time preference: A critical overview." Journal of Economic Literature, 40 (2), 351-401.

Frey, A., P. Taskinen, K. Schuette, M. Prenzel, C. Artelt, J. Baumert, W. Blum, M. Hammann, E. Klieme, R. Prekun, 2009.PISA 2006 Skalenhandbuch: Dokumentation der Erhebungsinstrumente. Waxmann. 
von Gaudecker, H. M., A. van Soest, and E. Wengstrom. 2011. "Heterogeneity in risky choice in a broad population." American Economic Review, 101, 664-694.

Gine, X., J. Goldberg, D. Silverman, and D. Yang, 2012. "Revising commitments: Field evidence on the adjustment of prior choices." NBER Working Paper No. 18065.

Gollier, C. and R. Zeckhauser, 2005. "Aggregation of Heterogeneous Time Preferences." Journal of Political Economy, 113 (4), 878-896.

Gul, F. and W. Pesendorfer, 2001. "Temptation and Self-Control." Econometrica 69 (6), 1403-35.

Hanushek, E. A. and L. Woessmann, 2011. "The economics of international differences in educational achievement." In E. A. Hanushek, S. Machin and L. Woessmann (eds.), Handbook of the Economics of Education, Vol. 3, Amsterdam: North Holland, 89-200.

Harless, D. W. and C. F. Camerer, 1994. "The predictive utility of generalized expected utility theories." Econometrica, 62 (6), 1251-1289.

Harrison, G. W., M. I. Lau, and M. B. Williams, 2002. "Estimating individual discount rates in Denmark: A field experiment." American Economic Review, 92 (5), 16061617.

Heller, K.A., Kratzmeier, H. and A. Lengfelder, 1998. Matrizen-Test-Manual, Bd. 1. Ein Handbuch zu den Standard Progressive Matrices von J. C. Raven. Göttingen: Beltz-Testgesellschaft.

Kuhn, M. A., P. Kuhn, and M. C. Villeval, 2013. "Self control and intertemporal choice: Evidence from glucose and depletion interventions." Working Paper.

Laibson, D., 1997. "Golden eggs and hyperbolic discounting." Quarterly Journal of Economics, 112 (2), 443-478. 
Loomes, G., P. G. Moffatt, and R. Sugden, 2002. "A microeconometric test of alternative stochastic theories of risky choice." Journal of Risk and Uncertainty, 24 (2), 103-130.

Luce, D., 1959. Individual choice behavior. New York: John Wiley \& Sons.

Lührmann, M., M. Serra-Garcia, and J. Winter, 2015. "Teaching teenagers in finance: Does it work?" Journal of Banking and Finance 54, 160-174.

Lusardi, A. and O. S. Mitchell, 2014. "The economic importance of financial literacy: Theory and evidence" Journal of Economic Literature, 52 (1), 5-44.

Lynch Jr., J. G., D. Fernandes, and R. G. Netemeyer, 2014. "Financial literacy, financial education, and downstream financial behaviors." Management Science, forthcoming.

Meier, S. and C. Sprenger, 2013. "Discounting financial literacy: time preferences and participation in financial education programs". Journal of Economic Behavior and Organization, 95, 159-174.

Moffitt, T. E., L. Arseneault, D. Belsky, N. Dickson, R. J. Hancox, H. Harrington, R. Houts, R. Poulton, B. W. Roberts, S. Ross, M. R. Sears, M. W. Thomson, A. Caspi, 2011. "A gradient of childhood self-control predicts health, wealth, and public safety." Proceedings of the National Academy of Sciences, 108(7), 2693-2698.

Moulton, B., 1986. "Random group effects and the precision of regression estimates." Journal of Econometrics, 32, 385-97.

My Finance Coach, 2012. Annual Report, http://www.myfinancecoach.com/.

Neal, D., 2013. "The Consequences of Using one Assesment System to Pursue two Objectives." Journal of Economic Education 44 (4), 339-352. 
O'Donoghue, T. and M. Rabin. "Doing it now or later." American Economic Review, 89 (1), 103-124.

Raven, J., 1989. "The Raven Progressive Matrices: A review of national norming studies and ethnic and socioeconomic variations within the United States." Journal of Educational Measurement, 26(1), 1-16.

Rook, D. W. and R. J. Fisher, 1995. Normative Influences on Impulsive Buying Behavior. Journal of Consumer Research 22 (3), 305-313.

Samuelson, P. A., 1937. "A note on measurement of utility." Review of Economic Studies, 4 (2), 155-161.

Sprenger, C., 2015. "Judging Experimental Evidence on Dynamic Inconsistency." American Economic Review Papers and Proceedings, forthcoming.

Sutter, M., M. G. Kocher, D. Glätzle-Rützler, and S. T. Trautmann, 2013. "Impatience and uncertainty: Experimental decisions predict adolescents' field behavior." American Economic Review, 103 (1), 510-531.

Strotz, R. H., 1956. "Myopia and inconsistency in dynamic utility maximization." Review of Economic Studies, 165-180.

Valence, G., A. d'Astous and Louis Fortier, 1988. "Compulsive Buying: Concept and Measurement." Journal of Consumer Policy 11, 419-433.

van Rooij, M., A. Lusardi and R. Alessie, 2011. "Financial literacy and stock market participation". Journal of Financial Economics, 101, 449-472.

Wooldridge, J., 2001. Econometric Analysis of Cross Section and Panel Data. The MIT Press, first edition. 


\section{APPENDIX}

\section{Appendix A: Instructions}

The instructions below were read aloud by the same experimenter at the beginning of each class visit. They are translated from German into English. Text in parenthesis and italics was not read aloud.

\section{Description of the experiment}

Welcome to our experiment. Our experiment today will consist of 2 parts. We will now go through the first part of the experiment. Please do not talk to your classmates and listen carefully. There will be breaks during the description of the experiment so that you can ask questions. Just raise your hand and someone will come to you.

In part 1 of the experiment you can earn money. We will ask you to choose between different payments, which you will receive at two different points in time. You will make several decisions on how to split money between an earlier point in time (e.g. today) and a later point in time (e.g. in 3 weeks). One of your decisions will be paid out in cash to you. You will only know which decision is paid out, once you have made all your decisions. We will determine it by drawing one decision at random in this classroom with your help. Each decision can be drawn for payment. Therefore, you should make each decision, as if it were the decision that is paid out.

Any questions so far?

We have brought an example to show you how it works. This example shows how your decisions could look like (put sheet on projector, show only the upper part including decision A1 only).

You have to decide between payments today and in 3 weeks from today. As you can see, there is a small calendar at the top of the sheet, in which we marked the exact corresponding dates. Today is colored in green, and in 3 weeks is colored in blue. Just below the calendar you can see the decisions you will be asked to make. The payments today and in 3 weeks are, respectively, colored in green and blue.

Let us look at the decision A1. For example, if I check the first box on the left, then I decide to get 12 Euro today and 0 Euro in 3 weeks. If I check the second box, then 
I decide to get 8 Euro today and 1 Euro in 3 weeks. If I check the third box, then I decide to get 4 Euro today and 2 Euro in 3 weeks. If I check the fourth box, then I decide to get 0 Euro today and 3 Euro in 3 weeks.

I have to check one of these four boxes. Suppose I would like to get 4 Euro today and 2 Euro in 3 weeks. Then, I will check the third box.

Any questions so far?

Please remember that we will pay out one of your decisions to you in cash. Therefore, choose each time what you really want. You indicate that by checking your preferred box. You may only check one of the four boxes in each row.

(Uncover sheet completely) As you can see, there are 7 rows on this sheet. The green payments, which you get today, become somewhat smaller in each row. The payments which you get in 3 weeks stay the same. As you can see, the last decision of this example (A7) would give you 30 cents today and 0 in 3 weeks if you check the first box. If you check the second box, how much will you get today and in 3 weeks? If you check the third box, how much will you get today and in 3 weeks? What about checking the fourth box?

In each row you make one decision, that is, you check one box. There is no right or wrong. You can decide differently in each row.

In this example most people choose the first option on the left in the beginning (in decision A1) and further down in the decision sheet they choose an option more to the right, for example the second, third, or fourth box. One possible way of making your decisions is thus to decide which option you prefer in the first row and then decide from which row onwards you would prefer a combination of payments to the right of the option you chose previously.

We will give you 3 sheets with different decisions. On each sheet the timing will be different. There are in total 3 different points in time: today, in 3 weeks, and in 6 weeks. The relevant points in time are indicated at the top of each sheet. Additionally, the exact dates are marked in the calendar.

Let us look at another example in which the points in time change. Here, it is (show sheet with decisions between 3 and 6 weeks). Here, you have to decide how much money you would like to get in 3 weeks and in 6 weeks. "In 3 weeks" is still colored in blue, while "in 6 weeks" is coloured in pink. Note that each point in time has its own color. Apart from that, the rules stay the same. In each row you have to make one decision 
which determines how much money you will get. Any questions so far?

How does the payment work?

After you have made all decisions on the 3 sheets, you will return your decision sheets for part 1 of the experiment to us. In total, you will have made 7 decisions per sheet, A1-A7, B1-B7, and C1-C7. We will then choose the decision relevant for your earnings. You will help us to choose one decision at random. For that purpose, there are small cards, one for each decision (show cards). One of you will blindly draw one card out of this bag. This card will determine the decision, which is relevant for your payment.

Let us turn to the most important point: Suppose, we draw decision C4. As you can see on the sheet, the relevant points in time for your payment are in 3 weeks and in 6 weeks (point to header). No matter which decisions you made, you will get an extra Euro for both points in time in order to thank you for your participation (use overhead marker to indicate extra euro above both points in time).

Suppose you chose the third box in C4. Then, in 3 weeks, you will get 1 Euro and 1.75 Euro, in total 2.75 Euro. In 6 weeks, you will get 1 Euro and 4 Euro, in total 5 Euro. Suppose you chose something else, for example the first box. Then, in 3 weeks you will get 5.25 Euro and 1 Euro, in total 6.25 Euro, and in 6 weeks 1 Euro.

Each of your 21 decisions can be drawn out of the bag. Thus, you should think about each decision very carefully.

How do you exactly receive your money?

Payments for today you will get at the end of this session. Payments at a later date, for example in 3 weeks, you will get in three weeks. We will come back and give you the money in class before the break starts or during the break. And in six weeks, the same will happen.

In order for us to know who gets how much money, we will give you a small card (show card). That is your receipt for your earnings. It is very important that you keep this card safe until we meet again. It helps us to know which decision you made. If you lose the card, your teacher will help us. He/She will safeguard a list with information on how much money you get at which point in time. At the end of this session, we will come to each of you and give you the card with your payments from part 1 . We will also ask you to put your name on the list next to the payments you will get at each point in time. 


\begin{tabular}{|c|c|c|}
\hline \multicolumn{2}{|c|}{ Research Team LMU München } & 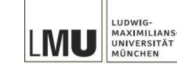 \\
\hline \multicolumn{3}{|c|}{$\begin{array}{l}\text { This pass lists the payments that you are entitled to by taking } \\
\text { part in our study. They will be paid out on the dates listed } \\
\text { during school breaks. }\end{array}$} \\
\hline \multicolumn{3}{|l|}{ Your payments: } \\
\hline Today & $\begin{array}{r}\text { In } 3 \text { weeks, } \\
\quad . \quad 2013 \\
\end{array}$ & $\begin{array}{r}\ln 6 \text { weeks, } \\
\quad .2013 \\
\end{array}$ \\
\hline Euro & Euro & Euro \\
\hline
\end{tabular}

Figure 1: Payment card (translated from German)

Now, please turn around the front page of part 1. There you can see another example. Please answer the questions on this sheet now and wait when you are done. We will go around and check your answers to make sure you understand everything.

\section{Exercise Sheet} Here we will ask you four questions to ensure that everybody has understood the rules. Let's
assume decision B5 has been drawn. You have made your decision as checked:

\begin{tabular}{|c|ccccc|}
\hline B5 & Payment TODAY... & $€ 5,10$ & $€ 3,40$ & $€ 1,70$ & $€ 0,00$ \\
& AND payment in 6 WEEKS & $€ 0,00$ & $€ 2,00$ & $€ 4,00$ & $€ 6,00$ \\
& & $\square$ & $\square$ & $\square$ & $\square$ \\
\hline
\end{tabular}

1. How much money from this decision will you receive TODAY?

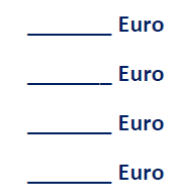

Figure 2: Example to test comprehension of CTB task (translated from German) 


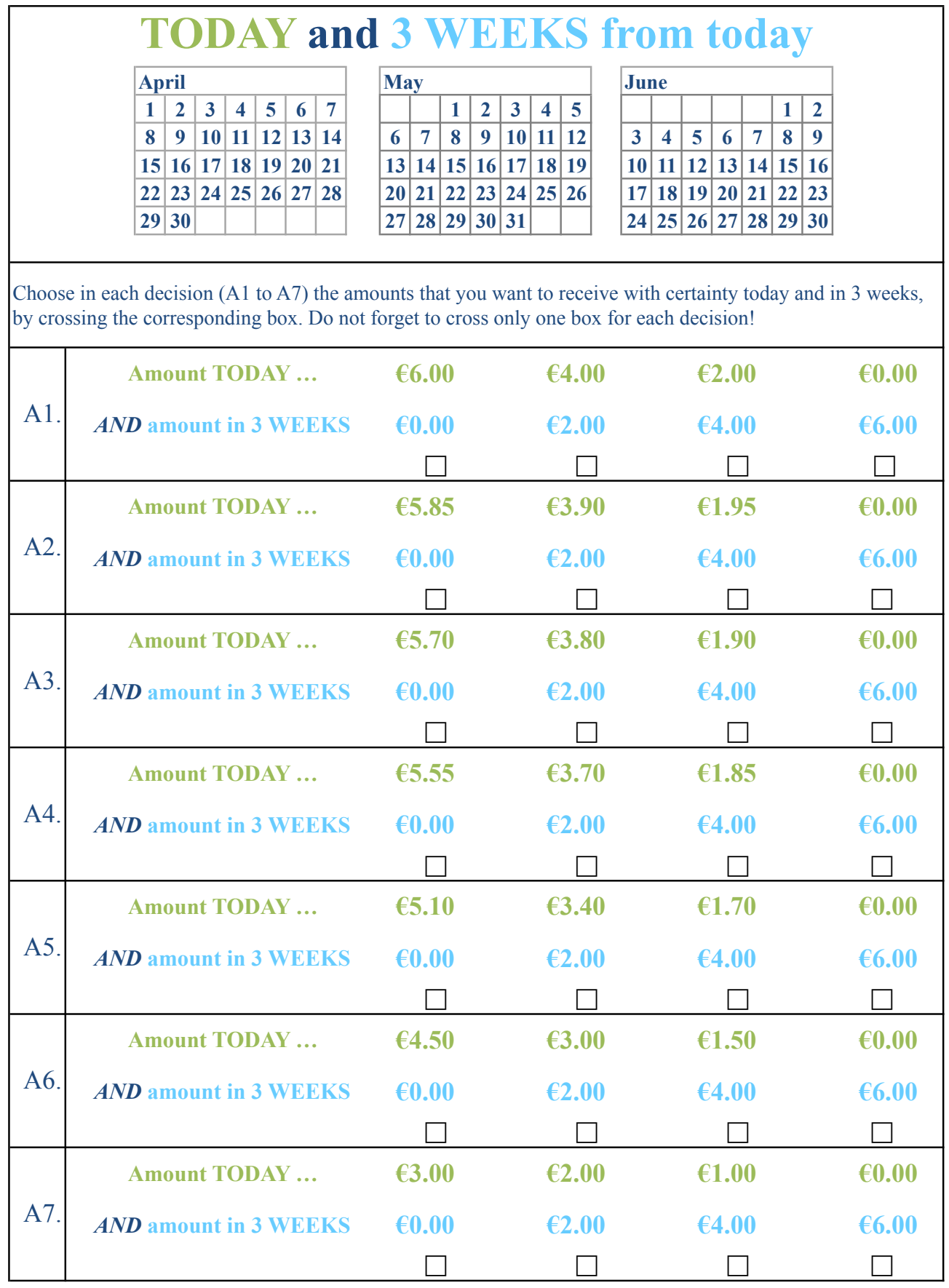

Figure 3: Decisions sheet for payment choices between today and in 3 weeks (translated from German) 


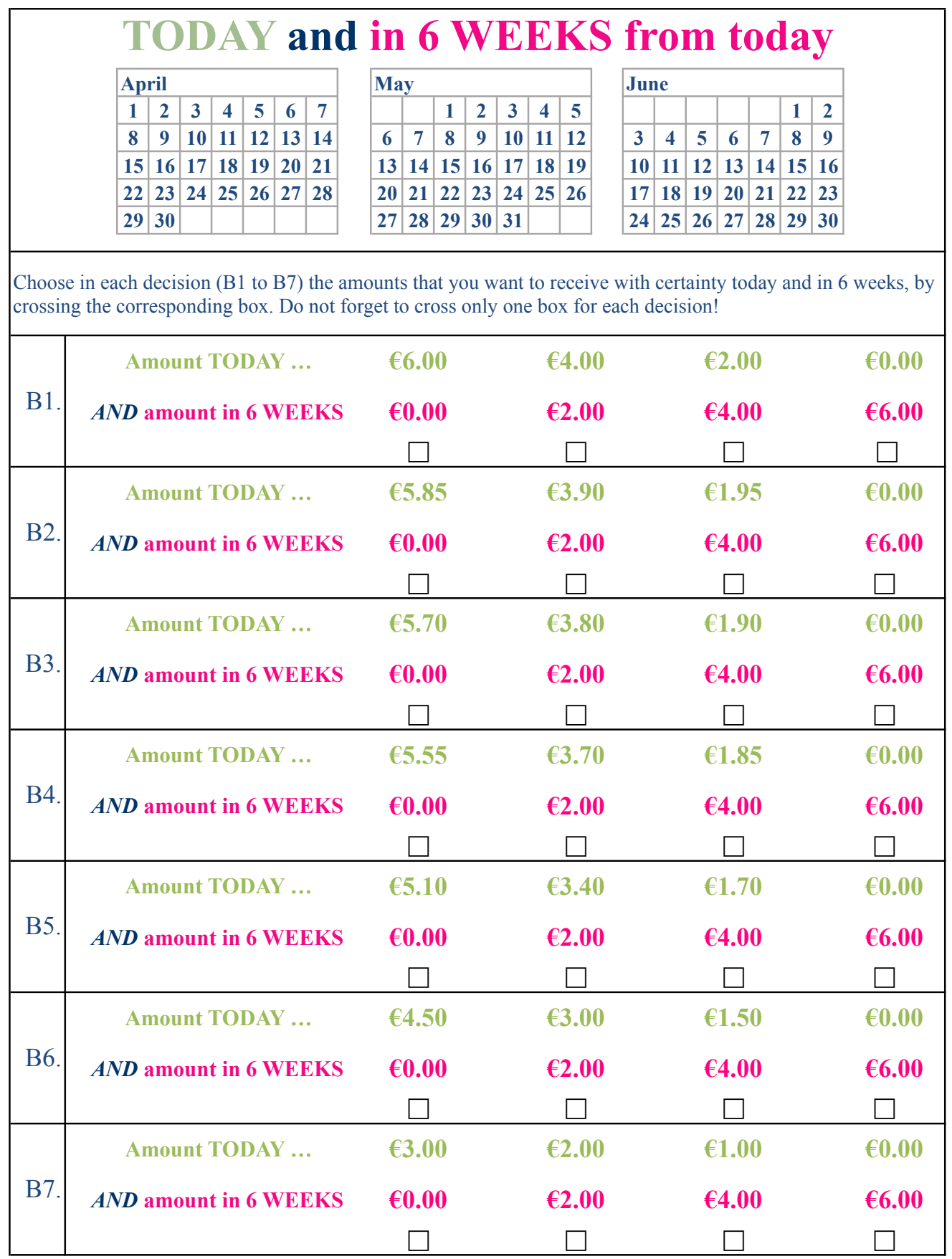

Figure 4: Decisions sheet for payment choices between today and in 3 weeks (translated from German) 


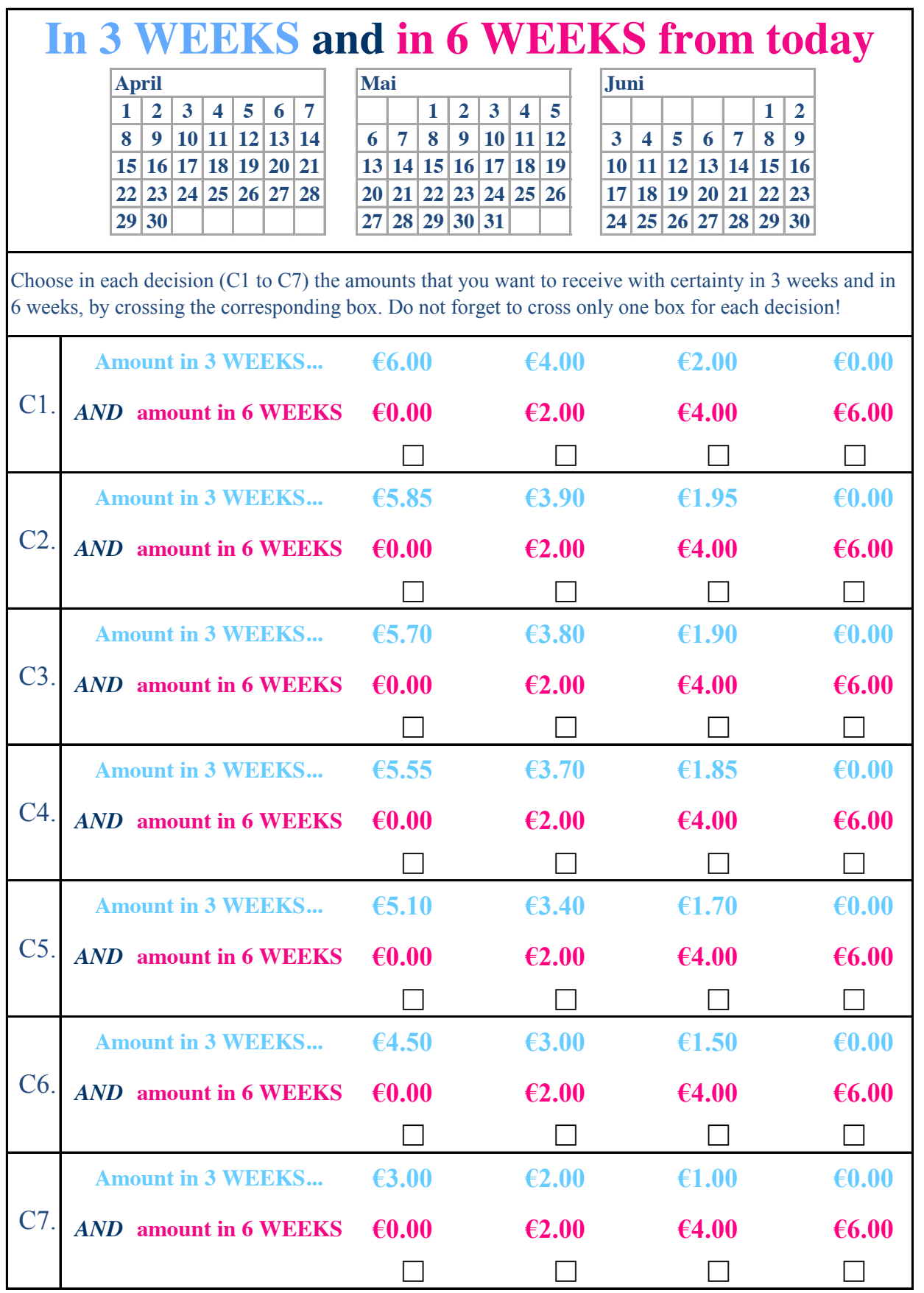

Figure 5: Decisions sheet for payment choices between today and in 3 weeks (translated from German) 


\section{Appendix B: Econometric Models}

\section{B.1. Interval Model Estimation}

Following Andreoni and Sprenger (2012), we assume a time separable CRRA utility function within the $\beta-\delta$ model of quasi-hyperbolic discounting (e.g., Laibson, 1997),

$$
U\left(x_{t}, x_{t+k}\right)=x_{t}^{\alpha}+\beta^{I_{t=0}} \delta^{k} x_{t+k}^{\alpha}
$$

where the individual receives monetary amounts $x_{t}$ and $x_{t+k}$ at time $t$ and $t+k$, and $I_{t=0}$ is an indicator variable that takes value one if payments are immediate. The preference parameters of interest are the discount rate $\delta$, present bias $\beta$ and curvature $\alpha$. Individuals maximize utility subject to the budget constraint, $(1+r) x_{t}+x_{t+k}=m$. This yields the standard Euler equation, which can be written in logs as:

$$
\ln \left(\frac{x_{t}}{x_{t+k}}\right)=\frac{\ln (\beta)}{\alpha-1} I_{t=0}+\frac{\ln (\delta)}{\alpha-1} k+\frac{1}{\alpha-1} \ln (1+r),
$$

The Euler equation establishes the optimal log ratio of payments across $t$ and $t+k, x_{j}^{*}=$ $\ln \left(\frac{x_{t, j}}{x_{t+k, j}}\right)$, in decision $j$, given the vector of preference parameters $\mu=\left(\frac{\ln (\beta)}{\alpha-1}, \frac{\ln (\delta)}{\alpha-1}, \frac{1}{\alpha-1}\right)$ and the vector of decision characteristics $X=\left(I_{t=0}, k, P\right)$. An individual $i$ is offered four possible $\log$ ratios $s_{m}$ in each decision problem $j$, where $m \in\{1, \ldots, M\}$ and $M=4$. Hence, we estimate an interval data model (Wooldridge, 2001, p. 509).

More specifically, let us denote the vector of possible ratios as $s=\left(s_{1}, s_{2}, s_{3}, s_{4}\right)$. To simplify notation we drop the subscripts for each individual $i$ and choice $j$. For each decision problem, an individual chooses

$$
s= \begin{cases}s_{1} & \text { if } x^{*}>s_{2} . \\ s_{2} & \text { if } s_{2}>x^{*}>s_{3} . \\ s_{3} & \text { if } s_{3}>x^{*}>s_{4} . \\ s_{4} & \text { if } s_{4}>x^{*}\end{cases}
$$

The probability that $s=s_{m}$, where $m \in\{1,2,3,4\}$, depends on $X^{\prime} \mu$. Additionally, as in von Gaudecker, van Soest and Wengström (2011) and Loomes, Moffatt and Sugden (2002), two forms of stochastic choice are modeled. First, Fechner errors, which enter as weight $\tau$ on $\varepsilon$, which is assumed to be i.i.d across choices and individuals, and follow a standard logistic distribution. Second, a trembling-hand error (e.g., Harless 
and Camerer, 1994), which allows for a probability $\omega$ that a student makes a random choice in a given decision. Hence, we have that,

$$
\left\{\begin{array}{l}
P\left(s=s_{1} \mid X, \mu, \tau, \omega, s\right)=(1-\omega)\left(1-\Lambda\left(\frac{1}{\tau}\left(s_{2}-X^{\prime} \mu\right)\right)\right)+\frac{\omega}{4}, \\
P\left(s=s_{2} \mid X, \mu, \tau, \omega, s\right)=(1-\omega)\left(\Lambda\left(\frac{1}{\tau}\left(s_{3}-X^{\prime} \mu\right)\right)-\Lambda\left(\frac{1}{\tau}\left(s_{2}-X^{\prime} \mu\right)\right)\right)+\frac{\omega}{4} \\
P\left(s=s_{3} \mid X, \mu, \tau, \omega, s\right)=(1-\omega)\left(\Lambda\left(\frac{1}{\tau}\left(s_{4}-X^{\prime} \mu\right)\right)-\Lambda\left(\frac{1}{\tau}\left(s_{3}-X^{\prime} \mu\right)\right)\right)+\frac{\omega}{4}, \\
P\left(s=s_{4} \mid X, \mu, \tau, \omega, s\right)=(1-\omega)\left(\Lambda\left(\frac{1}{\tau}\left(s_{4}-X^{\prime} \mu\right)\right)\right)+\frac{\omega}{4},
\end{array}\right.
$$

where $\Lambda(t)=\left(1+e^{-t}\right)^{-1}$. Thus, the conditional log-likelihood is

$$
\ln L\left(\mu, \tau, \omega ; X, s_{m}\right)=\sum_{i} \sum_{j} \ln \left(P_{i j}\left(s=s_{m} \mid \mu, \tau, \omega ; X, s\right) I_{\left(s=s_{m}\right)}\right)
$$

where $I_{\left(s=s_{m}\right)}$ is an indicator variable that takes value one if $s=s_{m}$.

\section{B.2. Luce Model}

An alternative stochastic choice model, which is frequently used in related studies, is the Luce model (e.g., Andersen et al., 2008). According to this model, the utility "index" of option $m$ is the ratio of its utility, weighted by an "error" parameter $\sigma$, over the sum of the utilities of all other options. In particular,

$$
u_{m}=\frac{U\left(x_{m, t}, x_{m, t+k}\right)^{\frac{1}{\sigma}}}{\sum_{n=1}^{M} U\left(x_{n, t}, x_{n, t+k}\right)^{\frac{1}{\sigma}}}
$$

As $\sigma \rightarrow 0$ choice collapses to the deterministic choice model, while as $\sigma$ increases choices become random. In this case, the likelihood that an individual chooses $m$ is $P\left(s=s_{m}\right)=P\left(u_{m}+\varepsilon>0\right)=\Phi\left(-u_{m}\right)$, where $\Phi(\cdot)$ is the cumulative standard normal distribution. 


\section{Appendix C}

\section{C.1 Aggregate Parameters: Sensitivity analysis}

In this section, we present the results of alternative specifications. First, in columns (1) and (2), we restrict $\omega$ to be homogeneous within the treatment and control groups respectively, instead of allowing school-level heterogeneity. In columns (3) and (4) we estimate the interval regression model without Fechner errors. Finally, in columns (5) and (6), we estimate the aggregate parameters using non linear least squares following Andreoni and Sprenger (2012). The same result is obtained in all specifications, $\hat{\beta}$ is significantly smaller than 1 in the control group and not significantly different from 1 in the treatment group.

Table C.1: Estimated Aggregate Parameters under alternative specifications

\begin{tabular}{|c|c|c|c|c|c|c|}
\hline & \multirow{2}{*}{\multicolumn{2}{|c|}{$\begin{array}{l}(1) \quad(2) \\
\text { Single trembling-hand error }\end{array}$}} & $(3)$ & & (5) & (6) \\
\hline & & & \multicolumn{2}{|c|}{ No Fechner error } & \multicolumn{2}{|c|}{ NLS } \\
\hline & Control & Treatment & Control & Treatment & Control & Treatment \\
\hline \multirow[t]{2}{*}{$\hat{\beta}$} & 0.915 & 0.996 & 0.934 & 0.996 & 0.971 & 1.001 \\
\hline & {$[0.028]$} & {$[0.011]$} & {$[0.021]$} & {$[0.014]$} & {$[0.016]$} & {$[0.012]$} \\
\hline \multirow[t]{2}{*}{$\hat{\delta}$} & 0.997 & 0.996 & 0.996 & 0.993 & 0.995 & 0.994 \\
\hline & {$[0.001]$} & {$[0.001]$} & {$[0.001]$} & {$[0.001]$} & {$[0.001]$} & {$[0.001]$} \\
\hline \multirow[t]{2}{*}{$\hat{\alpha}$} & 0.614 & 0.911 & 0.622 & 0.512 & 0.573 & 0.599 \\
\hline & {$[0.024]$} & {$[0.010]$} & {$[0.022]$} & {$[0.091]$} & {$[0.020]$} & {$[0.041]$} \\
\hline \multirow[t]{2}{*}{$\hat{\tau}$} & 0.411 & 0.594 & & & & \\
\hline & {$[0.077]$} & {$[0.077]$} & & & & \\
\hline Observations & 10,332 & 8,862 & 10,332 & 8,862 & 10,332 & 8,862 \\
\hline$H_{0}: \hat{\beta}=1$ ( $p$-value $)$ & 0.0021 & 0.7461 & 0.0013 & 0.7397 & 0.091 & 0.9649 \\
\hline
\end{tabular}

Note: Columns (1) and (2) report the estimated parameters by assuming $\omega$ is homogeneous within the treatment and control groups, respectively, in the interval regression model (as detailed in Online Appendix B.1). Columns (3) and (4) report the estimated parameters modifying the interval regression model such that Fechner errors are not allowed. As in Table 6, $\omega$ is estimated at the school level in columns (3) and (4). Columns (5) and (6) report the estimated preference parameters using the nonlinear least square specification in Andreoni and Sprenger (2012), setting the Stone-Geary consumption minima parameters equal to zero. All parameters are computed as nonlinear combinations, using the Delta method, of parameters estimated using maximum likelihood. 


\section{C.2. Extended Tables}

Table C.2 presents the estimated coefficients of individual characteristics for Table 5. Table C.3 present the estimated coefficients of individual characteristics for Table 8 and Table C. 4 does the same for Table 9.

Table C.2. Consistent choices and corner choices

\begin{tabular}{|c|c|c|c|c|}
\hline & $\begin{array}{l}(1) \\
\text { Consiste }\end{array}$ & $\begin{array}{c}(2) \\
\text { at choice }\end{array}$ & $\stackrel{(3)}{\text { Corn }}$ & $\begin{array}{c}(4) \\
\text { r choice }\end{array}$ \\
\hline \multirow[t]{2}{*}{ Treatment } & $0.053^{*}$ & $0.054^{*}$ & $0.068^{*}$ & $0.078^{* * *}$ \\
\hline & {$[0.030]$} & {$[0.028]$} & {$[0.040]$} & {$[0.029]$} \\
\hline \multirow{2}{*}{ Immediate payment } & 0.004 & 0.012 & $0.034^{*}$ & $0.047^{* *}$ \\
\hline & {$[0.023]$} & {$[0.020]$} & {$[0.019]$} & {$[0.020]$} \\
\hline \multirow[t]{2}{*}{ Delay is $6 \mathrm{w}$. } & 0.008 & 0.006 & -0.007 & -0.023 \\
\hline & {$[0.025]$} & {$[0.024]$} & {$[0.027]$} & {$[0.026]$} \\
\hline \multirow[t]{2}{*}{ Gross interest } & $0.045^{* * *}$ & $0.052^{* * *}$ & 0.009 & 0.015 \\
\hline & {$[0.017]$} & {$[0.017]$} & {$[0.014]$} & {$[0.013]$} \\
\hline \multirow[t]{2}{*}{ Gross interest $*$ Immediate } & 0.003 & -0.004 & -0.004 & -0.016 \\
\hline & {$[0.016]$} & {$[0.015]$} & {$[0.014]$} & {$[0.016]$} \\
\hline \multirow[t]{2}{*}{ Gross interest $*$ Delay is $6 \mathrm{w}$. } & -0.004 & -0.002 & 0.003 & 0.015 \\
\hline & {$[0.020]$} & {$[0.020]$} & {$[0.019]$} & {$[0.019]$} \\
\hline \multirow[t]{2}{*}{ Treatment $*$ Immediate } & -0.001 & 0.001 & -0.013 & -0.016 \\
\hline & {$[0.010]$} & {$[0.011]$} & {$[0.013]$} & {$[0.012]$} \\
\hline \multirow[t]{2}{*}{ Treatment $*$ Delay is $6 \mathrm{w}$. } & -0.014 & $-0.013^{*}$ & 0.010 & 0.011 \\
\hline & {$[0.009]$} & {$[0.007]$} & {$[0.013]$} & {$[0.013]$} \\
\hline \multirow[t]{2}{*}{ Treatment $*$ Gross interest } & -0.020 & -0.022 & -0.018 & -0.026 \\
\hline & {$[0.019]$} & {$[0.020]$} & {$[0.017]$} & {$[0.016]$} \\
\hline \multirow[t]{2}{*}{ Female } & & $-0.050 * * *$ & & $-0.175^{* * *}$ \\
\hline & & {$[0.009]$} & & {$[0.026]$} \\
\hline \multirow[t]{2}{*}{ Grade 8} & & 0.009 & & 0.017 \\
\hline & & {$[0.018]$} & & {$[0.035]$} \\
\hline \multirow[t]{2}{*}{ Cognition score } & & 0.008 & & 0.011 \\
\hline & & {$[0.007]$} & & {$[0.016]$} \\
\hline \multirow[t]{2}{*}{ Math grade } & & $0.017 * * *$ & & 0.005 \\
\hline & & {$[0.005]$} & & {$[0.011]$} \\
\hline \multirow[t]{2}{*}{ Migrant background } & & -0.008 & & -0.007 \\
\hline & & {$[0.011]$} & & {$[0.022]$} \\
\hline \multirow[t]{2}{*}{ Single parent } & & -0.000 & & 0.041 \\
\hline & & {$[0.012]$} & & {$[0.026]$} \\
\hline \multirow[t]{2}{*}{$<25$ books at home } & & $-0.022^{* *}$ & & -0.031 \\
\hline & & {$[0.009]$} & & {$[0.021]$} \\
\hline Add. Controls & No & Yes & No & Yes \\
\hline Observations & 16,452 & 15,192 & 19,194 & 17,724 \\
\hline
\end{tabular}

Note: Probit regression, marginal effects shown, with robust standard errors clustered at the school level ( 25 clusters). Consistent choice takes value 1 if the choice is consistent with the law of demand, 0 otherwise. Corner choice takes value 1 if the choice was to allocate 0 or $100 \%$ of the budget to the sooner payment date. Individual characteristics (gender, grade, cognition score, relative math grade, migrant background, single parent and books at home) are defined as in Table 3. Columns (2) and (4) include month and location fixed effects. ${ }^{* * *}, * *, *$ indicate significance at the 1,5 and 10 percent level, respectively. 
C.3. Treatment effect on time consistency and individual-level time preference parameters

\begin{tabular}{|c|c|c|c|c|}
\hline & $\begin{array}{c}(1) \\
\text { Time } \\
\text { Consistency }\end{array}$ & $\begin{array}{c}(2) \\
\text { Present bias parameter } \\
\left(\hat{\beta}_{i}\right)\end{array}$ & $\begin{array}{c}(3) \\
\text { Discount factor } \\
\left(\hat{\delta}_{i}\right)\end{array}$ & $\begin{array}{c}(4) \\
\text { Trembling-hand error } \\
\left(\hat{\omega}_{i}\right)\end{array}$ \\
\hline Treatment & $\begin{array}{r}0.099 * * \\
{[0.042]}\end{array}$ & $\begin{array}{l}-0.033 \\
{[0.057]}\end{array}$ & $\begin{array}{r}0.009 \\
{[0.007]}\end{array}$ & $\begin{array}{r}-0.073^{* * *} \\
{[0.015]}\end{array}$ \\
\hline Female & $\begin{array}{r}0.015 \\
{[0.031]}\end{array}$ & $\begin{array}{r}0.026 \\
{[0.056]}\end{array}$ & $\begin{array}{r}0.008 \\
{[0.007]}\end{array}$ & $\begin{array}{l}-0.015 \\
{[0.015]}\end{array}$ \\
\hline Grade 8 & $\begin{array}{r}-0.066 \\
{[0.046]}\end{array}$ & $\begin{array}{r}0.032 \\
{[0.062]}\end{array}$ & $\begin{array}{l}0.013^{*} \\
{[0.008]}\end{array}$ & $\begin{array}{r}0.005 \\
{[0.017]}\end{array}$ \\
\hline Cognition score & $\begin{array}{r}0.01 \\
{[0.015]}\end{array}$ & $\begin{array}{r}0.002 \\
{[0.031]}\end{array}$ & $\begin{array}{l}-0.002 \\
{[0.004]}\end{array}$ & $\begin{array}{l}-0.013 \\
{[0.008]}\end{array}$ \\
\hline Math grade & $\begin{array}{r}0.017 \\
{[0.012]}\end{array}$ & $\begin{array}{r}0.015 \\
{[0.028]}\end{array}$ & $\begin{array}{r}0.001 \\
{[0.003]}\end{array}$ & $\begin{array}{r}0.005 \\
{[0.008]}\end{array}$ \\
\hline Migrant background & $\begin{array}{r}0.002 \\
{[0.029]}\end{array}$ & $\begin{array}{l}-0.081 \\
{[0.056]}\end{array}$ & $\begin{array}{r}0.008 \\
{[0.007]}\end{array}$ & $\begin{array}{l}-0.006 \\
{[0.015]}\end{array}$ \\
\hline Single parent & $\begin{array}{r}0.031 \\
{[0.029]}\end{array}$ & $\begin{array}{r}-0.087 \\
{[0.064]}\end{array}$ & $\begin{array}{l}-0.008 \\
{[0.008]}\end{array}$ & $\begin{array}{r}0.002 \\
{[0.017]}\end{array}$ \\
\hline$<25$ books at home & $\begin{array}{r}0.018 \\
{[0.028]}\end{array}$ & $\begin{array}{l}-0.025 \\
{[0.057]}\end{array}$ & $\begin{array}{r}0.003 \\
{[0.007]}\end{array}$ & $\begin{array}{l}-0.021 \\
{[0.015]}\end{array}$ \\
\hline Constant & & $\begin{array}{r}1.017^{* * *} \\
{[0.139]}\end{array}$ & $\begin{array}{r}0.969^{* * *} \\
{[0.017]}\end{array}$ & $\begin{array}{r}0.258^{* * *} \\
{[0.037]}\end{array}$ \\
\hline $\begin{array}{l}\text { Observations } \\
\text { Adj. R-squared }\end{array}$ & 749 & $\begin{array}{r}749 \\
0.037\end{array}$ & $\begin{array}{r}749 \\
0.013\end{array}$ & $\begin{array}{r}749 \\
0.047\end{array}$ \\
\hline
\end{tabular}

Note: Column (1) reports the marginal effects of a probit model on the likelihood that an individual is time-consistent, i.e., $\hat{\beta}_{i}$ falls within $0.99<\hat{\beta}_{i}<1.01$. Columns $(2-4)$ report multivariate regression results on all estimated time preference parameters. Treatment is a dummy variable that takes value 1 if the student participated in the education program. Individual characteristics (gender, grade, cognition score, relative math grade, migrant background, single parent and books at home) are defined as in Table 3. All specifications include month and location fixed effects. Robust standard errors, clustered at the school level, are computed. ${ }^{* * *},{ }^{* *},{ }^{*}$ indicate significance at the 1,5 and 10 percent level, respectively. 
Table C.4. Estimated parameters and field behaviors

\begin{tabular}{|c|c|c|c|c|}
\hline & $\begin{array}{c}(1) \\
\text { Save }(0 / 1)\end{array}$ & $\begin{array}{c}(2) \\
\text { If save }=1 \\
\operatorname{Ln}(\text { save })\end{array}$ & $\begin{array}{c}(3) \\
\text { Impulsivity }\end{array}$ & $\begin{array}{c}\text { (4) } \\
\text { Saving goals }\end{array}$ \\
\hline Present bias $\left(\hat{\beta}_{i}\right)$ & $\begin{array}{r}0.092 \\
{[0.099]}\end{array}$ & $\begin{array}{r}0.283^{* * * *} \\
{[0.064]}\end{array}$ & $\begin{array}{l}-0.069 \\
{[0.052]}\end{array}$ & $\begin{array}{r}0.113^{* *} \\
{[0.052]}\end{array}$ \\
\hline Discount factor $\left(\hat{\delta}_{i}\right)$ & $\begin{array}{l}-0.039 \\
{[2.537]}\end{array}$ & $\begin{array}{r}4.016^{* *} \\
{[1.767]}\end{array}$ & $\begin{array}{r}0.938 \\
{[1.743]}\end{array}$ & $\begin{array}{r}1.964 \\
{[1.150]}\end{array}$ \\
\hline Trembling-hand error $\left(\hat{\omega}_{i}\right)$ & $\begin{array}{r}0.149 \\
{[0.308]}\end{array}$ & $\begin{array}{l}-0.070 \\
{[0.421]}\end{array}$ & $\begin{array}{r}0.112 \\
{[0.294]}\end{array}$ & $\begin{array}{r}0.446 \\
{[0.268]}\end{array}$ \\
\hline Treatment & $\begin{array}{r}0.299 \\
{[2.595]}\end{array}$ & $\begin{array}{r}3.316 \\
{[2.186]}\end{array}$ & $\begin{array}{r}0.685 \\
{[1.850]}\end{array}$ & $\begin{array}{r}2.833^{* *} \\
{[1.253]}\end{array}$ \\
\hline$\hat{\beta}_{i} *$ Treatment & $\begin{array}{r}0.023 \\
{[0.124]}\end{array}$ & $\begin{array}{r}-0.227^{*} \\
{[0.116]}\end{array}$ & $\begin{array}{r}0.109 \\
{[0.071]}\end{array}$ & $\begin{array}{l}-0.055 \\
{[0.098]}\end{array}$ \\
\hline$\hat{\delta}_{i} *$ Treatment & $\begin{array}{l}-0.396 \\
{[2.533]}\end{array}$ & $\begin{array}{l}-3.098 \\
{[2.185]}\end{array}$ & $\begin{array}{l}-0.845 \\
{[1.797]}\end{array}$ & $\begin{array}{r}-2.649^{* *} \\
{[1.196]}\end{array}$ \\
\hline$\hat{\omega}_{i} *$ Treatment & $\begin{array}{r}-0.081 \\
{[0.428]}\end{array}$ & $\begin{array}{c}-0.594 \\
{[0.507]}\end{array}$ & $\begin{array}{r}0.206 \\
{[0.422]}\end{array}$ & $\begin{array}{l}-0.410 \\
{[0.371]}\end{array}$ \\
\hline Female & $\begin{array}{r}-0.231^{* *} \\
{[0.098]}\end{array}$ & $\begin{array}{l}-0.051 \\
{[0.119]}\end{array}$ & $\begin{array}{r}0.175^{* *} \\
{[0.080]}\end{array}$ & $\begin{array}{r}-0.329^{* * *} \\
{[0.067]}\end{array}$ \\
\hline Grade 8 & $\begin{array}{l}-0.167 \\
{[0.112]}\end{array}$ & $\begin{array}{r}0.182 \\
{[0.114]}\end{array}$ & $\begin{array}{r}0.108 \\
{[0.076]}\end{array}$ & $\begin{array}{r}0.017 \\
{[0.114]}\end{array}$ \\
\hline Cognition score & $\begin{array}{r}0.061 \\
{[0.040]}\end{array}$ & $\begin{array}{r}-0.098^{*} \\
{[0.056]}\end{array}$ & $\begin{array}{r}-0.039 \\
{[0.042]}\end{array}$ & $\begin{array}{r}0.004 \\
{[0.036]}\end{array}$ \\
\hline Math grade & $\begin{array}{r}0.117^{* *} \\
{[0.059]}\end{array}$ & $\begin{array}{l}-0.010 \\
{[0.053]}\end{array}$ & $\begin{array}{l}-0.049 \\
{[0.041]}\end{array}$ & $\begin{array}{r}0.105^{* * *} \\
{[0.037]}\end{array}$ \\
\hline Migrant background & $\begin{array}{l}-0.027 \\
{[0.110]}\end{array}$ & $\begin{array}{r}-0.027 \\
{[0.112]}\end{array}$ & $\begin{array}{r}0.025 \\
{[0.059]}\end{array}$ & $\begin{array}{r}0.072 \\
{[0.055]}\end{array}$ \\
\hline Single parent & $\begin{array}{r}0.072 \\
{[0.117]}\end{array}$ & $\begin{array}{l}-0.016 \\
{[0.112]}\end{array}$ & $\begin{array}{r}-0.010 \\
{[0.082]}\end{array}$ & $\begin{array}{r}0.047 \\
{[0.082]}\end{array}$ \\
\hline$<25$ books at home & $\begin{array}{r}-0.293^{* * *} \\
{[0.075]}\end{array}$ & $\begin{array}{r}0.102 \\
{[0.103]}\end{array}$ & $\begin{array}{l}-0.032 \\
{[0.087]}\end{array}$ & $\begin{array}{l}-0.041 \\
{[0.067]}\end{array}$ \\
\hline Constant & $\begin{array}{r}0.037 \\
{[2.604]}\end{array}$ & $\begin{array}{l}-0.583 \\
{[1.856]}\end{array}$ & $\begin{array}{l}-0.885 \\
{[1.775]}\end{array}$ & $\begin{array}{r}-2.378^{*} \\
{[1.214]}\end{array}$ \\
\hline $\begin{array}{l}\text { Observations } \\
\text { Adj. R-squared }\end{array}$ & 749 & $\begin{array}{r}371 \\
0.079\end{array}$ & $\begin{array}{r}730 \\
0.030\end{array}$ & $\begin{array}{r}734 \\
0.080\end{array}$ \\
\hline
\end{tabular}

Note: Column (1) reports estimated marginal effects of a probit model on the likelihood that an individual saves. Columns (2-4) report OLS regression results on the natural logarithm of savings, conditional on savings, self-reported impulsivity and efficacy at achieving saving goals. The latter two measures are standardized. The parameters $\hat{\beta}_{i}, \hat{\delta}_{i}$ and $\hat{\omega}_{i}$ are obtained through the joint estimation of time preference parameters as outlined in Section 5.1. Individual characteristics (gender, grade, cognition score, relative math grade, migrant background, single parent and books at home) are defined as in Table 3. Robust standard errors, clustered at the school level, are computed. ***, **, * indicate significance at the 1,5 and 10 percent level, respectively. 


\section{C.3 Individual Parameters: CRRA curvature and Fechner error estimates}

Below we present detailed results on the estimated values of $\alpha$ and $\tau$ at the individual level. Table C.5 presents the descriptive statistics for these parameters and Table C.6 present the treatment effects. Columns (3) to (8) in Table C.6 and in Table 8 in the paper are estimated using multivariate regression. We apply this variant of Zellner's seemingly unrelated regression model since the preference parameters are jointly estimated from the same set of choices, and are thus correlated.

Table C.5: Descriptive statistics for the estimated CRRA curvature parameter $(\alpha)$ and Fechner error $(\tau)$

\begin{tabular}{cccccc}
\hline & & $5^{t h}$ & $25^{t h}$ & $75^{t h}$ & $95^{t h}$ \\
& Median & Percentile & Percentile & Percentile & Percentile \\
\hline Control & & & & & \\
$\hat{\alpha}_{i}$ & 0.473 & -1.411 & 0.097 & 0.736 & 1.738 \\
$\hat{\tau}_{i}$ & 0.335 & 0.025 & 0.225 & 0.515 & 1.867 \\
$\begin{array}{c}\text { Treatment } \\
\hat{\alpha}_{i}\end{array}$ & 0.334 & -3.341 & -0.007 & 0.697 & 1.332 \\
$\hat{\tau}_{i}$ & 0.350 & 0.042 & 0.278 & 0.457 & 0.903 \\
\hline
\end{tabular}


Table C.6: Treatment effect on the estimated CRRA curvature parameter $(\alpha)$ and Fechner error $(\tau)$

\begin{tabular}{|c|c|c|c|c|}
\hline & \multicolumn{2}{|c|}{$\begin{array}{c}\text { CRRA curvature parameter } \\
\hat{\alpha}_{i}\end{array}$} & \multicolumn{2}{|c|}{$\begin{array}{c}\text { Fechner error } \\
\hat{\tau}_{i}\end{array}$} \\
\hline Treatment & $\begin{array}{r}-0.272^{*} \\
{[0.151]}\end{array}$ & $\begin{array}{l}-0.266 \\
{[0.168]}\end{array}$ & $\begin{array}{l}-0.068 \\
{[0.057]}\end{array}$ & $\begin{array}{l}-0.057 \\
{[0.062]}\end{array}$ \\
\hline Female & & $\begin{array}{l}-0.022 \\
{[0.166]}\end{array}$ & & $\begin{array}{l}-0.036 \\
{[0.061]}\end{array}$ \\
\hline Grade 8 & & $\begin{array}{l}-0.111 \\
{[0.185]}\end{array}$ & & $\begin{array}{l}-0.020 \\
{[0.068]}\end{array}$ \\
\hline Cognition score & & $\begin{array}{r}0.087 \\
{[0.093]}\end{array}$ & & $\begin{array}{r}0.011 \\
{[0.034]}\end{array}$ \\
\hline Math grade & & $\begin{array}{r}0.051 \\
{[0.084]}\end{array}$ & & $\begin{array}{r}0.023 \\
{[0.031]}\end{array}$ \\
\hline Migrant background & & $\begin{array}{r}0.106 \\
{[0.168]}\end{array}$ & & $\begin{array}{r}0.010 \\
{[0.062]}\end{array}$ \\
\hline Single parent & & $\begin{array}{l}-0.069 \\
{[0.191]}\end{array}$ & & $\begin{array}{r}0.056 \\
{[0.070]}\end{array}$ \\
\hline$<25$ books at home & & $\begin{array}{r}0.070 \\
{[0.168]}\end{array}$ & & $\begin{array}{l}0.113^{*} \\
{[0.062]}\end{array}$ \\
\hline Constant & $\begin{array}{r}0.355^{* * *} \\
{[0.102]}\end{array}$ & $\begin{array}{r}-0.103 \\
{[0.414]}\end{array}$ & $\begin{array}{r}0.544^{* * *} \\
{[0.038]}\end{array}$ & $\begin{array}{r}0.182 \\
{[0.152]}\end{array}$ \\
\hline $\begin{array}{l}\text { Observations } \\
\text { Adj. R-squared }\end{array}$ & $\begin{array}{r}815 \\
0.004\end{array}$ & $\begin{array}{r}749 \\
0.018\end{array}$ & $\begin{array}{r}815 \\
0.002\end{array}$ & $\begin{array}{r}749 \\
0.039\end{array}$ \\
\hline
\end{tabular}

Note: This table contains the estimated effect of treatment on $\hat{\alpha}_{i}$ and $\hat{\tau}_{i}$, using multivariate regression results on all estimated time preference parameters. Treatment is a dummy variable that takes value 1 if the student participated in the education program. Individual characteristics (gender, grade, cognition score, relative math grade, migrant background, single parent and books at home) are defined as in Table 3. Columns (2) and (4) also include month and location fixed effects. Robust standard errors, clustered at the school level, are computed. ${ }^{* * *}, * *, *$ indicate significance at the 1,5 and 10 percent level, respectively. 